\title{
Effects of feeding various dosages of Saccharomyces cerevisiae fermentation product in transition dairy cows
}

\author{
E. M. Zaworski, ${ }^{\star}$ C. M. Shriver-Munsch, ${ }^{\star}$ N. A. Fadden, ${ }^{\star}$ W. K. Sanchez, $\dagger$ I. Yoon, $\dagger$ and G. Bobe ${ }^{\star} \ddagger^{1}$ \\ *Department of Animal and Rangeland Sciences, Oregon State University, Corvallis 97331 \\ †Diamond V, Cedar Rapids, IA 52404 \\ ‡Linus Pauling Institute, Oregon State University, Corvallis 97331
}

\section{ABSTRACT}

Feeding 56 versus $0 \mathrm{~g} / \mathrm{d}$ of Saccharomyces cerevisiae fermentation product (SCFP; Diamond V Original XP; Diamond V, Cedar Rapids, IA) can increase feed intake and milk production in transition dairy cows. To evaluate the effects of various dosages of SCFP, Holstein cows were given individually a supplement containing 0 ( $\mathrm{n}=$ 14), $56(\mathrm{n}=15)$, or $112 \mathrm{~g}(\mathrm{n}=13)$ of SCFP daily during morning lockup as a topdressing to their total mixed ration. The supplement consisted of 0,56 , or $112 \mathrm{~g}$ of SCFP mixed with $84 \mathrm{~g}$ of molasses and 168, 112, or 56 $\mathrm{g}$ of corn meal, respectively. Supplement feeding began $28 \mathrm{~d}$ before predicted calving date (no less than $14 \mathrm{~d}$ ) and ended $28 \mathrm{~d}$ postpartum, and supplement intake was evaluated daily. Blood samples were collected at d -21 , $-14,-7,-3,-1,0,1,3,7,14,21$, and 28 to measure serum concentrations of macrominerals, metabolites, acute-phase proteins, immunoglobulin, and hormones. Milk weights were measured and milk samples were collected 2 times/wk on nonconsecutive days and analyzed for milk fat, protein, lactose, and somatic cell count (SCC). During the first day after calving, feeding SCFP versus no SCFP decreased serum cortisol concentrations and at least tended to increase supplement intake and serum concentrations of calcium, glucose, urea N, and serum amyloid A. During the first 4 wk postpartum, feeding SCFP versus no SCFP decreased milk SCC and increased milk production and serum phosphorus concentrations. Feeding 112 versus $56 \mathrm{~g}$ of SCFP/d did not show additional effects. Feeding SCFP may have a dosage-independent beneficial effect in supporting the physiologic adaptations after parturition, resulting in higher milk production and lower milk SCC.

Key words: dairy cow, immune function, metabolic status, yeast culture

Received November 7, 2013.

Accepted January 26, 2014.

${ }^{1}$ Corresponding author: gerd.bobe@oregonstate.edu

\section{INTRODUCTION}

The transition period, generally defined as 3 wk prepartum to 3 wk postpartum, is a critical time period in the life of dairy cows because increased nutritional and energy demands exceed intake, resulting in tremendous physiological challenges to maintain homeostasis at the onset of lactation (Overton and Waldron, 2004). The physiological challenges include immune function, which is suppressed in the transition period, resulting in increased disease susceptibility (Nonnecke et al., 2003; Ohtsuka et al., 2006). Feeding ruminal fermentation modifiers during the transition period could be a costeffective and safe way to increase DMI and maximize feed utilization and thereby improve milk production and decrease the risk of disease (Eastridge, 2006). One of the most widely used ruminal fermentation modifiers is the Saccharomyces cerevisiae fermentation product (SCFP; Original XP; Diamond V, Cedar Rapids, IA). Saccharomyces cerevisiae fermentation product improves dietary nutrient and energy availability and milk production by promoting cellulolytic, proteolytic, and lactate-utilizing bacteria in the rumen (Harrison et al., 1988; Callaway and Martin, 1997). Feeding 56 to 60 $\mathrm{g}$ of SCFP/d to transition dairy cows increased DMI and milk production by 2 to $5 \%$, on average (Robinson and Garrett, 1999; Dann et al., 2000; Ramsing et al., 2009). Results in dairy calves, pigs, and chicken suggest that feeding SCFP may also improve immune function (Magalhães et al., 2008; Gao et al., 2009; Shen et al., 2009 ) by activating the innate and adaptive immune response (Jensen et al., 2008c).

We hypothesized that higher dosages of SCFP may be required during the transition period to overcome the nutrient and energy demands associated with parturition and onset of lactation. Dose-response studies of feeding SCFP to lactating dairy cows are limited. We previously compared feeding 0,57 , and $227 \mathrm{~g}$ of SCFP/d to transition dairy cows and observed no differences in lactation performance, energy status, and feed intake behavior between 57 and $227 \mathrm{~g} / \mathrm{d}$ (Ramsing et al., 2009). The objectives of this study were to determine in transition dairy cows (1) the effects of periparturient 
SCFP supplementation on indicators of macromineral status (serum calcium, magnesium, and phosphorus), nutrient status (serum glucose and urea N), energy status (BCS and serum NEFA and BHBA), inflammation as part of the innate immune status [haptoglobin and serum amyloid A (SAA)], adaptive immune status ( $\operatorname{IgG}$, IgM, and $\operatorname{IgA}$ ), and hormones involved in these physiological processes (cortisol and insulin) and (2) the effects of feeding 112 versus $56 \mathrm{~g}$ of SCFP/d, which, to our knowledge, have not been examined.

\section{MATERIALS AND METHODS}

\section{Animals and Diets}

All procedures involving animals were conducted in accordance with Oregon State University (Corvallis) Institutional Animal Care and Use (ACUP no. 3991). The study was conducted on a commercial dairy farm close to Oregon State University. To be eligible for the study, cows had to be purebred Holsteins, healthy, have completed $\geq 1$ lactation, and have a BCS of $\geq 3.0$ at the start of the study. Cows ( $\mathrm{n}=45 ; 2$ to 6 upcoming parities) were blocked by upcoming parity (2 or 3 and higher) and randomly assigned within blocks to treatments. Calving dates and previous 305-d mature equivalent values were evenly represented across treatments. The treatment consisted of 0 (control), 56, or $112 \mathrm{~g}$ of SCFP/d mixed with $84 \mathrm{~g}$ of molasses and 168, 112 , or $56 \mathrm{~g}$ of corn meal, respectively (Table 1). Daily, the supplement was top-dressed individually to each cow during the morning feeding when cows were locked in head stanchion lockups for a period of 30 to $45 \mathrm{~min}$. The treatment period started $4 \mathrm{wk}$ before the expected calving date and ended $4 \mathrm{wk}$ after calving. Three cows did not complete the study because of treatment-unrelated causes ( 1 cow developed prepartum leg and feet problems; 1 cow developed prepartum toxic mastitis; 1 cow had her uterus torn at calving). The remaining 42 cows (control: 14 cows, $56 \mathrm{~g}$ of SCFP/d: 15 cows, and $112 \mathrm{~g}$ of $\mathrm{SCFP} / \mathrm{d}: 13$ cows) completed the study and were used for statistical analysis.

During the last 4 wh before expected calving, cows were housed in a straw-bedded freestall barn and were fed once in the morning $(0730 \mathrm{~h})$ a TMR based on corn, corn silage, and alfalfa and triticale hay, which met NRC (2001) guidelines (Table 2). After calving, cows stayed the first $48 \mathrm{~h}$ in the hospital pen, and then for the remaining $26 \mathrm{~d}$ in the early lactation pen. Cows that had twins (control: 1 cow; $56 \mathrm{~g}$ of SCFP/d: 5 cows; and $112 \mathrm{~g}$ of SCFP/d: 2 cows) or appeared lethargic after giving birth, or both, received i.v. 0.5 L calcium-magnesium-phosphorus-potassium-dextrose (CMPK) solution (Aspen Veterinary Resources Ltd.,
Liberty, MO) and $0.5 \mathrm{~L}$ of dextrose (50\% dextrose; Aspen Veterinary Resources Ltd.) and orally a 37.85-L drench [907 g of Fresh Cow Drench (TPi, Madera, CA) and $237 \mathrm{~mL}$ of propylene glycol dissolved in $37.85 \mathrm{~L}$ of water]. Cows diagnosed with infectious or metabolic disorders stayed or were moved in the hospital pen for treatment. Cows from the hospital and early-lactation pen were fed at 0700 and $0900 \mathrm{~h}$, respectively, and 1330 $\mathrm{h}$ for all cows, a TMR based on corn, corn silage, and alfalfa hay, which met NRC (2001) guidelines (Table 2). The TMR was tested for nutrient composition by Dairy One Inc. (Ithaca, NY). Cows in the hospital and earlylactation pen were milked 2 and 6 times/d, respectively.

During the study period, cows were monitored daily for abnormal milk, gait, appetite, general appearance, alertness, vaginal discharge, and retained placenta. Uterine discharge was checked 2 times/wk. Urinary ketones and body temperature were checked if the cow appeared unhealthy, which included depressed feed intake (feeding behavior of all cows were monitored daily), lethargy, cold ears, and rapid BCS loss. Infectious and metabolic disorders were diagnosed and treated based on standard operating procedures developed by the Oregon State University veterinary staff and consistent with standards of veterinary care practices. Diagnosis and treatment of infectious and metabolic disorders was done by the herd manager who was trained and supervised by the Oregon State University veterinarian, who came at least once per week to supervise diagnosis and treatment of infectious and metabolic disorders. The herd manager was blinded to the dietary treatment allocation. Except for emergencies, cows were treated during morning lockup and after blood samples were taken.

\section{Data Collection}

Three trained evaluators independently determined BCS on a 5-point scale (Edmonson et al., 1989). Start-

Table 1. Composition of dietary supplements

\begin{tabular}{|c|c|c|c|}
\hline \multirow[b]{2}{*}{ Ingredient (g) } & \multicolumn{3}{|c|}{ Treatment $^{1}$} \\
\hline & Control & $\begin{array}{c}56 \mathrm{~g} \\
\text { of SCFP/d }\end{array}$ & $\begin{array}{c}112 \mathrm{~g} \\
\text { of } \mathrm{SCFP} / \mathrm{d}\end{array}$ \\
\hline $\operatorname{SCFP}^{2}(\mathrm{~g} / \mathrm{d})$ & 0 & 56 & 112 \\
\hline Corn eal $^{3}(\mathrm{~g} / \mathrm{d})$ & 168 & 112 & 56 \\
\hline $\operatorname{Molasses}^{4}(\mathrm{~g} / \mathrm{d})$ & 84 & 84 & 84 \\
\hline
\end{tabular}

${ }^{1} \mathrm{SCFP}=$ Saccharomyces cerevisiae fermentation product (Diamond V Original XP; Diamond V, Cedar Rapids, IA).

${ }^{2}$ Minimum of $12.0 \% \mathrm{CP}$, minimum of $3.0 \%$ crude fat, and maximum of $6.5 \%$ crude fiber.

${ }^{3}$ CHS Nutrition (Sioux Falls, SD).

${ }^{4}$ Minimum of $5.0 \%$ CP, minimum of $33.0 \%$ total sugars, and maximum of $35 \%$ moisture (CHS Nutrition). 
Table 2. Feed and nutrient composition of pre- and postpartum diets

\begin{tabular}{|c|c|c|}
\hline \multirow{2}{*}{$\begin{array}{l}\text { Feed composition } \\
\text { ( } \% \text { of diet DM, unless otherwise noted) }\end{array}$} & \multicolumn{2}{|c|}{ Diet } \\
\hline & Prepartum & Postpartum \\
\hline Grass silage & & 2.13 \\
\hline Alfalfa hay ( $20 \%$ CP, $36 \% \mathrm{NDF}$ ) & 13.42 & 19.26 \\
\hline Corn silage & 27.77 & 20.93 \\
\hline Triticale hay (9\% CP, $60 \%$ NDF) & 13.69 & \\
\hline Beet pulp & 3.41 & \\
\hline Vitamin and mineral premix ${ }^{1}$ & 4.95 & \\
\hline Vitamin and mineral premix ${ }^{2}$ & & 2.96 \\
\hline $\mathrm{MgOx}^{3}$ & 0.18 & \\
\hline Ground corn & 18.15 & \\
\hline Corn (high-moisture ear corn) & & 20.00 \\
\hline Corn distillers grains (including solubles) & 8.06 & 12.33 \\
\hline Canola meal & 6.69 & 6.40 \\
\hline Wheat distillers grains (including solubles) & & 5.97 \\
\hline Bakery by-product & & 6.39 \\
\hline EnerGII Regular ${ }^{4}$ & 1.82 & 1.74 \\
\hline Limestone (ground) & 1.85 & 0.94 \\
\hline Sodium bicarbonate & & 0.94 \\
\hline Analyzed nutrient composition & & \\
\hline $\mathrm{NE}_{\mathrm{L}}($ Mcal $/ \mathrm{kg}, \mathrm{DM}$ basis $)$ & 1.63 & 1.70 \\
\hline $\mathrm{CP}$ & 13.0 & 18.7 \\
\hline $\mathrm{ADF}$ & 27.1 & 16.9 \\
\hline $\mathrm{NDF}$ & 36.2 & 27.2 \\
\hline Ether extract & 3.47 & 6.18 \\
\hline Calcium & 2.42 & 0.68 \\
\hline Phosphorus & 0.42 & 0.44 \\
\hline Magnesium & 0.46 & 0.32 \\
\hline Potassium & 1.30 & 1.23 \\
\hline Sodium & 0.072 & 0.243 \\
\hline Iron (mg/kg) & 469 & 570 \\
\hline Zinc $(\mathrm{mg} / \mathrm{kg})$ & 83 & 115 \\
\hline Copper $(\mathrm{mg} / \mathrm{kg})$ & 23 & 23 \\
\hline Manganese (mg/kg) & 65 & 91 \\
\hline Molybdenum ( $\mathrm{mg} / \mathrm{kg})$ & 0.6 & 0.5 \\
\hline
\end{tabular}

${ }^{1}$ Provides to the diet DM $6.7 \mathrm{~g} / \mathrm{kg}$ of $\mathrm{Ca}$ as calcium propionate, -carbonate, -chloride, and monodicalcium phosphate; $1.4 \mathrm{~g} / \mathrm{kg}$ of $\mathrm{P}$ as monodicalcium phosphate; $8.0 \mathrm{~g} / \mathrm{kg}$ of $\mathrm{Cl}$ as ammonium and calcium chloride; 3.4 $\mathrm{g} / \mathrm{kg}$ of $\mathrm{Mg}$ as magnesium sulfate; $30 \mathrm{mg} / \mathrm{kg}$ of $\mathrm{K} ; 0.99 \mathrm{~g} / \mathrm{kg}$ of S as magnesium, manganese, copper, cobalt, and zinc sulfate; $0.17 \mathrm{mg} / \mathrm{kg}$ of Co as cobalt sulfate; $15.2 \mathrm{mg} / \mathrm{kg}$ of $\mathrm{Cu}$ as copper sulfate; $1.012 \mathrm{mg} / \mathrm{kg}$ of I as ethylenediamine dihydroiodide; $7.7 \mathrm{mg} / \mathrm{kg}$ of $\mathrm{Mn}$ as manganese sulfate; $0.31 \mathrm{mg} / \mathrm{kg}$ of Se as sodium selenite; $29.9 \mathrm{mg} / \mathrm{kg}$ of $\mathrm{Zn}$ as zinc sulfate; $10.8 \mathrm{kIU} / \mathrm{kg}$ of vitamin $\mathrm{A} ; 4.6 \mathrm{kIU} / \mathrm{kg}$ of vitamin $\mathrm{D}_{3} ; 167 \mathrm{IU} / \mathrm{kg}$ of vitamin E as all-rac- $\alpha$-tocopheryl acetate; $1.19 \mathrm{~g} / \mathrm{kg}$ of choline; $1.00 \mathrm{~g} / \mathrm{kg}$ of niacin; and $26.8 \mathrm{mg} / \mathrm{kg}$ of monensin.

${ }^{2}$ Provides to the diet DM $0.30 \mathrm{~g} / \mathrm{kg}$ of $\mathrm{Ca}, 0.23 \mathrm{~g} / \mathrm{kg}$ of P from ammonium polyphosphate, $0.20 \mathrm{~g} / \mathrm{kg}$ of $\mathrm{Mg}$, $1.23 \mathrm{~g} / \mathrm{kg}$ of $\mathrm{K}, 0.21 \mathrm{~g} / \mathrm{kg}$ of Na, $0.19 \mathrm{~g} / \mathrm{kg}$ of Cl, $0.26 \mathrm{~g} / \mathrm{kg}$ of S, $0.07 \mathrm{mg} / \mathrm{kg}$ of Co as cobalt sulfate, $0.05 \mathrm{mg} /$ $\mathrm{kg}$ of $\mathrm{Co}$ as organic cobalt, $12.4 \mathrm{mg} / \mathrm{kg}$ of $\mathrm{Cu}$ as copper sulfate, $4.42 \mathrm{mg} / \mathrm{kg}$ of $\mathrm{Cu}$ as organic copper, $1.76 \mathrm{mg} /$ $\mathrm{kg}$ of I as ethylenediamine dihydroiodide, $10.7 \mathrm{mg} / \mathrm{kg}$ of $\mathrm{Mn}$ as manganese sulfate, $0.81 \mathrm{mg} / \mathrm{kg}$ of $\mathrm{Mn}$ as organic manganese, $0.25 \mathrm{mg} / \mathrm{kg}$ of Se as sodium selenite, $59.0 \mathrm{mg} / \mathrm{kg}$ of $\mathrm{Zn}$ as zinc sulfate, $8.00 \mathrm{mg} / \mathrm{kg}$ of $\mathrm{Zn}$ as organic zinc, $5.01 \mathrm{kIU} / \mathrm{kg}$ of vitamin A, $1.23 \mathrm{kIU} / \mathrm{kg}$ of vitamin $\mathrm{D}_{3}, 24.5 \mathrm{IU} / \mathrm{kg}$ of vitamin $\mathrm{E}$ as all-rac- $\alpha$-tocopheryl acetate, and $0.25 \mathrm{~g} / \mathrm{kg}$ of methionine.

${ }^{3}$ Guaranteed to contain no less than $56 \% \mathrm{Mg}$ (Baymag Inc., Calgary, AB, Canada).

${ }^{4}$ Contains (DM basis) $90.4 \%$ total fat and $9.6 \% \mathrm{Ca}$ as calcium salts of long-chain FA (Inman and Co., Clackamas, OR).

ing before the first supplement feeding, scores were given once per week during the supplement-feeding period. Supplement consumption was monitored daily and recorded as completely or not completely consumed. Cows had $15 \mathrm{~min}$ to consume the entire supplement before the leftovers of the supplement were removed. During the $15 \mathrm{~min}$, the cows' feeding behaviors were visually monitored and recorded by 1 to 3 trained evaluators, who were blinded to treatment allocation. Milk produc- tion was measured and milk samples were collected by a certified milk tester from Willamette Valley DHIA (Salem, OR) twice per week on nonconsecutive days.

Blood samples were collected from the coccygeal vein or artery during morning lockup within 10 min of feeding. Prepartum blood samples were collected weekly starting at $28 \mathrm{~d}$ before the predicted calving date and every other day close to calving. Postpartum, blood samples were collected on d 0 (morning after calving), 
$1,3,7,14,21$, and 28. Blood samples were collected in serum Vacutainer tubes (BD Vacutainer Plus plastic serum tubes; BD Diagnostics, Franklin Lakes, NJ) and placed on ice immediately after collection. Serum was separated after centrifugation at $1,600 \times g$ for $20 \mathrm{~min}$ at room temperature, and frozen at $-20^{\circ} \mathrm{C}$ until analysis.

\section{Sample Analysis}

Milk samples were analyzed for fat, protein, lactose, and SCC by mid-infrared spectrophotometry at Willamette Valley DHIA. Fat-corrected milk (3.5\%) yield was calculated as follows: $3.5 \% \mathrm{FCM}=[0.4324 \times$ milk $(\mathrm{kg} / \mathrm{d})]+[16.2165 \times$ fat $(\mathrm{kg} / \mathrm{d})]$. Serum concentrations of calcium (Stanbio Total Calcium LiquiColor Proc. No. 0150), magnesium (Stanbio Magnesium LiquiColor Proc. No. 0130), phosphorus (Stanbio Phosphorus Liqui-UV Procedure No. 0830), glucose (Stanbio Glucose Procedure No. 1075), BHBA (Stanbio BHBA LiquiColor Procedure No. 2440), urea N (Stanbio Urea Nitrogen Liqui-UV Procedure No. 2020; all Stanbio Laboratory, Boerne, TX), NEFA [acyl-CoA synthetaseacyl CoA oxidase (ACS ACOD) method; WAKO Diagnostics, Richmond, VA], SAA (catalog no. KAA0021; an ELISA assay using conjugated antibodies that were verified for bovine SAA; Life Technologies Corp., Grand Island, NY), haptoglobin (catalog no. 2410-70; an ELISA assay using conjugated anti-bovine antibodies; Life Diagnostics Inc., West Chester, PA), IgG (catalog no. E10-118; an ELISA assay using conjugated anti-bovine antibodies; Bethyl Laboratories Inc., Montgomery, TX), IgM (catalog no. E10-101; an ELISA assay using conjugated anti-bovine antibodies; Bethyl Laboratories Inc.), IgA (catalog no. E10-121; an ELISA assay using conjugated anti-bovine antibodies; Bethyl Laboratories Inc.), insulin (catalog no. ERK B1009; an ELISA assay using conjugated anti-bovine antibodies; Endocrine Technologies Inc., Newark, CA), and cortisol (catalog no. ERK B1004; an ELISA assay using conjugated anti-bovine antibodies; Endocrine Technologies Inc.), were measured according to manufacturers' instructions using a FLUOstar Omega microplate autoreader (BMG Labtech Inc., San Francisco, CA). The inter- and intraassay coefficients of variation were below $10 \%$ for all analytes. Sampling times corresponded to d -28 (at first supplement feeding; baseline sample), -21 ( -24 to -18$),-14$ ( -17 to -11$),-7$ ( -10 to -5$),-3(-4$ or -3$),-1$ ( -2 or -1 ), 0 (morning after calving), 1, 3, $7,14,21$, and 28 postpartum. Insulin and cortisol were measured only between $\mathrm{d}-7$ and 7 postpartum.

\section{Statistical Analysis}

Data were analyzed in a repeated-measures-in-time randomized block design using PROC MIXED of SAS
(SAS Institute, 2001). To achieve a normal distribution, milk SCC and serum concentrations of glucose and NEFA were natural logarithm transformed and serum concentrations of haptoglobin, BHBA, insulin, and cortisol were twice natural logarithm transformed. The variance-covariance structure of repeated measures within cow was modeled using the heterogeneous firstorder autoregressive variance-covariance matrix, except for serum insulin and cortisol concentrations for which the homogeneous first-order autoregressive variancecovariance matrix was used.

Fixed effects in the statistical model were SCFP dosage $(0,56$, or $112 \mathrm{~g}$ of $\mathrm{SCFP} / \mathrm{d}$ ), sampling time (day relative to calving for blood and milk; week relative to calving for BCS), parity (second and third and higher), milking frequency $(2 \times$ or $6 \times$, included in the model only for milk yield and components), and the interaction between SCFP dosage and sampling time. For serum analytes and BCS, concentrations and values measured at the start of the study were added as linear covariates into the model if they were significant, which was the case for BCS and all analytes except for calcium, haptoglobin, and SAA. To obtain the correct degrees of freedom, the KENWARDROGER option was invoked. The KENWARDROGER option consists of the Satterthwaite adjustment for degrees of freedom with a Kenward-Roger adjustment on standard errors, which can be used for repeated-measures studies.

To evaluate the compliance rate, we calculated for each cow the percentage of days the cow completely consumed her supplement prepartum and postpartum. Compliance at the morning after calving was much lower than for the remaining feeding period and was, therefore, analyzed separately; PROC GLIMMIX was used to analyze percentage compliance rate, assuming a binomial distribution. Fixed effects in the model were SCFP dosage and parity. The Fisher exact test was used to compare the number of cows per group with infectious and metabolic disorders or treatments.

The 2 a priori comparisons were effect of SCFP supplementation (both SCFP dosages combined versus control) and SCFP dosage (112 vs. $56 \mathrm{~g} / \mathrm{d}$ ) using the ESTIMATE statement. Values presented in the figures and tables are least squares means and standard error of the mean transformed back to their original measurement scale. All statistical tests were 2-sided. The $P$-values were not adjusted for testing of multiple serum components. Statistical significance was declared at $P \leq 0.05$ and a tendency at $0.05<P \leq 0.10$.

\section{RESULTS}

Cows quickly adapted to the feed supplement, as all cows finished their supplement on the first day 
Table 3. Effect of feeding Saccharomyces cerevisiae fermentation product (SCFP) on milk yield and composition in Holstein cows during the first 4 wk postpartum

\begin{tabular}{|c|c|c|c|c|c|}
\hline \multirow[b]{2}{*}{ Item } & \multicolumn{3}{|c|}{ Treatment $(\mathrm{LSM} \pm \mathrm{SEM})$} & \multicolumn{2}{|c|}{$P$-value of contrast ${ }^{1}$} \\
\hline & $\begin{array}{c}0 \mathrm{~g} \text { of SCFP } / \mathrm{d} \\
(\mathrm{n}=14)\end{array}$ & $\begin{array}{c}56 \mathrm{~g} \text { of SCFP } / \mathrm{d} \\
(\mathrm{n}=15)\end{array}$ & 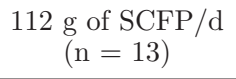 & $\begin{array}{c}\text { Control } \\
\text { vs. SCFP }\end{array}$ & $\begin{array}{l}56 \text { vs. } 112 \text { g } \\
\text { of } \mathrm{SCFP} / \mathrm{d}\end{array}$ \\
\hline \multicolumn{6}{|l|}{ Amount $(\mathrm{kg} / \mathrm{d})$} \\
\hline Milk & $36.1 \pm 2.0$ & $40.7 \pm 1.9$ & $41.8 \pm 2.0$ & 0.03 & 0.69 \\
\hline $3.5 \% \mathrm{FCM}$ & $41.9 \pm 2.2$ & $45.6 \pm 2.0$ & $46.2 \pm 2.2$ & 0.11 & 0.83 \\
\hline Fat & $1.62 \pm 0.09$ & $1.73 \pm 0.08$ & $1.73 \pm 0.09$ & 0.29 & 0.95 \\
\hline Protein & $1.09 \pm 0.06$ & $1.22 \pm 0.06$ & $1.24 \pm 0.06$ & 0.05 & 0.82 \\
\hline Lactose & $1.69 \pm 0.10$ & $1.91 \pm 0.09$ & $1.99 \pm 0.10$ & 0.03 & 0.55 \\
\hline $\mathrm{TS}$ & $9.69 \pm 0.51$ & $10.70 \pm 0.47$ & $10.93 \pm 0.51$ & 0.06 & 0.73 \\
\hline \multicolumn{6}{|l|}{ Composition (\%) } \\
\hline Fat & $4.73 \pm 0.18$ & $4.48 \pm 0.16$ & $4.37 \pm 0.18$ & 0.12 & 0.61 \\
\hline Protein & $3.06 \pm 0.05$ & $3.07 \pm 0.04$ & $3.02 \pm 0.05$ & 0.76 & 0.45 \\
\hline Lactose & $4.64 \pm 0.05$ & $4.67 \pm 0.05$ & $4.73 \pm 0.05$ & 0.39 & 0.42 \\
\hline TS & $12.41 \pm 0.17$ & $12.20 \pm 0.16$ & $12.08 \pm 0.17$ & 0.18 & 0.61 \\
\hline $\mathrm{SCC}($ cells $/ \mu \mathrm{L})$ & $162 \pm 40$ & $75 \pm 17$ & $88 \pm 22$ & 0.02 & 0.63 \\
\hline
\end{tabular}

${ }^{1}$ Probabilities of orthogonal contrasts. Control versus SCFP tests the effect of SCFP supplementation; 56 versus $112 \mathrm{~g}$ of SCFP/d tests the effect of SCFP dosage.

of feeding. Cows had a high compliance rate to the supplement, as cows finished their supplement $96.2 \pm$ $1.5 \%$ (control), $98.7 \pm 0.8 \%$ (56 g of $\mathrm{SCFP} / \mathrm{d})$, and $96.3 \pm 1.5 \%(112 \mathrm{~g}$ of $\mathrm{SCFP} / \mathrm{d})$ of the days prepartum $\left(P_{\text {Supplementation }}=0.31 ; P_{\text {Dosage }}=0.18\right)$ and $89.3 \pm 3.3 \%$ (control), $89.0 \pm 3.2 \%$ (56 g of $\mathrm{SCFP} / \mathrm{d}$ ), and 89.4 $\pm 3.4 \%$ (112 g of $\mathrm{SCFP} / \mathrm{d})$ of the days postpartum $\left(P_{\text {Supplementation }}=0.99 ; P_{\text {Dosage }}=0.94\right)$. We focused on the supplement intake directly after calving, when cows were switched from the close-up to the early-lactation diet. In the morning after calving, a higher proportion of SCFP-supplemented (56 g of SCFP/d: $80 \pm 11 \%$; $112 \mathrm{~g}$ of $\mathrm{SCFP} / \mathrm{d}: 92 \pm 8 \%)$ versus control cows $(51 \pm$ $14 \%)$ finished their supplement $\left(P_{\text {Supplementation }}=0.03\right.$; $\left.P_{\text {Dosage }}=0.39\right)$.

\section{Effect of SCFP Supplementation and Dosage on Milk Yield and Composition}

Cows that received SCFP produced $5.2 \pm 2.3 \mathrm{~kg} / \mathrm{d}$ more milk during the first 4 wk postpartum than control cows $(P=0.03$; Table 3$)$. The increase in milk production in response to SCFP feeding was not dosage dependent $(P=0.69)$. Group differences in milk production were similar across week of lactation $(P=$ $0.67)$. Besides milk production, protein $(P=0.05)$, lactose $(P=0.03)$, and TS $(P=0.06)$ production were or tended to be increased with SCFP feeding. Milk composition was not significantly affected by SCFP supplementation or dosage, except for SCC (Table 3). Cows supplemented with SCFP had dosage-independently $(P$ $=0.63)$ lower SCC in their milk than control cows $(P$ $=0.02$ ). None of the SCFP-fed cows developed clinical mastitis, whereas 2 control cows developed clinical mastitis. Ten control cows had at least 2 milk tests with $\mathrm{SCC}>200$ cells $/ \mu \mathrm{L}($ milk $\mathrm{SCC}>200$ cells $/ \mu \mathrm{L}$ has been proposed as an indicator of subclinical mastitis; Sharma et al., 2011), whereas 5 (56 g of SCFP/d) and $4(112 \mathrm{~g}$ of SCFP/d) SCFP-fed cows had at least 2 milk tests with $\mathrm{SCC}>200$ cells $/ \mu \mathrm{L}\left(P_{\text {Supplementation }}=0.02\right.$; $\left.P_{\text {Dosage }}=1.00\right)$. Group differences in SCC were similar across week of lactation $(P=0.88)$.

\section{Effect of SCFP Supplementation and Dosage on Indicators of Macromineral Status}

Overall, SCFP supplementation $(P=0.68)$ and dosage $(P=0.66)$ did not affect serum calcium concentrations (Figure 1A). As clinical milk fever is defined as the clinical manifestation of hypocalcemia within the first $48 \mathrm{~h}$ after calving (Kelton et al., 1998), we specifically focused on this time period. During the first 48 $\mathrm{h}$ after calving, SCFP-supplemented cows tended to have dosage-independently $(P=0.40)$ greater calcium concentrations than control cows $(7.97 \pm 0.17$ vs. 7.49 $\pm 0.23 \mathrm{mg} / \mathrm{dL} ; P=0.10)$. Furthermore, fewer SCFPfed cows (56 g of SCFP/d: 8 cows; $112 \mathrm{~g}$ of SCFP/d: 9 cows) than control cows (13 cows) had calcium concentrations below $8 \mathrm{mg} / \mathrm{dL}\left(P_{\text {Supplementation }}=0.04 ; P_{\text {Dosage }}\right.$ $=0.70$ ), which are indicative of hypocalcemia (Goff, 2008). None of the cows were recumbent. Calcium concentrations below $6 \mathrm{mg} / \mathrm{dL}$, indicative of clinical milk fever (Goff, 2008; Reinhardt et al., 2011), were measured in 3 (control), 2 (56 g of SCFP/d), and 1 (112 $\mathrm{g}$ of SCFP/d) cows during the first $48 \mathrm{~h}$ after calving. As group difference in calcium treatment could have affected serum calcium concentrations during the first $48 \mathrm{~h}$ after calving, we evaluated whether SCFP feed- 
ing affected the number of cows treated with calcium within the first $48 \mathrm{~h}$ after calving (control: 3 cows; 56 $\mathrm{g}$ of SCFP/d: 6 cows; $112 \mathrm{~g}$ of $\mathrm{SCFP} / \mathrm{d}$ : 5 cows) and observed no group differences $\left(P_{\text {Supplementation }}=0.31\right.$; $\left.P_{\text {Dosage }}=1.00\right)$. Furthermore, higher calcium concentrations in SCFP-fed versus control cows started before calving, as SCFP-fed cows had higher calcium concentrations than control cows on the last day before calving ( $8.74 \pm 0.13$ vs. $8.31 \pm 0.17 \mathrm{mg} / \mathrm{dL} ; P=0.05)$.

Saccharomyces cerevisiae fermentation product supplementation and dosage did not affect serum magnesium concentrations overall $\left(P_{\text {Supplementation }}=0.33\right.$; $\left.P_{\text {Dosage }}=0.82\right)$ or during the first $48 \mathrm{~h}$ after calving $\left(P_{\text {Supplementation }}=0.20 ; P_{\text {Dosage }}=0.31 ;\right.$ Figure 1B $)$. Cows receiving 112 versus $56 \mathrm{~g}$ of $\mathrm{SCFP} / \mathrm{d}$ tended to have higher magnesium concentrations during the last week before parturition $(P=0.09)$, which was significant 1 wk before calving $(2.78 \pm 0.13$ vs. $2.40 \pm 0.10 \mathrm{mg} /$ $\mathrm{dL} ; P=0.02)$. Except for 2 cows receiving $56 \mathrm{~g}$ of $\mathrm{SCFP} / \mathrm{d}$, none of the cows had serum magnesium concentrations below $1.8 \mathrm{mg} / \mathrm{dL}$, which is indicative of hypomagnesemia (Goff, 2008), during the first $48 \mathrm{~h}$ after calving. Overall, SCFP-fed cows tended to have dosage-independently $(P=0.38)$ higher serum phosphorus concentrations than control cows $(6.46 \pm 0.09$ vs. $6.17 \pm 0.12 \mathrm{mg} / \mathrm{dL} ; P=0.06)$, which was significant for the postpartal period $(6.21 \pm 0.12$ vs. $5.81 \pm 0.16$ $\mathrm{mg} / \mathrm{dL} ; P=0.05)$ but not for any single sampling time (Figure 1C). The largest differences in phosphorus concentrations with SCFP supplementation were observed directly after calving $(6.63 \pm 0.38$ vs. $5.58 \pm 0.53 \mathrm{mg} /$ dL).

\section{Effect of SCFP Supplementation and Dosage on Indicators of Nutrient and Energy Status}

Overall, SCFP supplementation and dosage did not affect serum concentrations of glucose $\left(P_{\text {Supplementation }}=0.59 ; P_{\text {Dosage }}=0.66 ;\right.$ Figure $\left.2 \mathrm{~A}\right)$ and urea N $\left(P_{\text {Supplementation }}=0.13 ; P_{\text {Dosage }}=0.55\right.$; Figure $\left.2 \mathrm{~B}\right)$. Similar to serum calcium, an effect of SCFP supplementation was observed during the first $48 \mathrm{~h}$ after calving, as SCFP-fed cows tended to have or had higher serum glucose $(75.2 \pm 2.5$ vs. $68.0 \pm 3.1 \mathrm{mg} / \mathrm{dL} ; P=0.06$; Figure $2 \mathrm{~A})$ and urea $\mathrm{N}$ concentrations $(10.8 \pm 1.0$ vs. $8.6 \pm 1.2 \mathrm{mg} / \mathrm{dL} ; P=0.05$; Figure $2 \mathrm{~B}$ ) than control cows. Outside the immediate postpartal period, no significant effects on serum glucose and urea $\mathrm{N}$ were observed except for higher urea $\mathrm{N}$ concentrations in cows receiving 112 vs. $56 \mathrm{~g}$ of $\mathrm{SCFP} / \mathrm{d}$ at d 28 postpartum $(10.4 \pm 1.1$ vs. $8.3 \pm 1.1 \mathrm{mg} / \mathrm{dL} ; P=0.05)$.

Overall or at any specific time point, SCFP supplementation and dosage did not affect serum concentrations of NEFA $\left(P_{\text {Supplementation }}=0.92 ; P_{\text {Dosage }}=0.29\right.$;
Figure $3 \mathrm{~A})$ and BHBA $\left(P_{\text {Supplementation }}=0.83 ; P_{\text {Dosage }}=\right.$ 0.80 ; Figure $3 \mathrm{~B})$ and BCS $\left(P_{\text {Supplementation }}=0.69 ; P_{\text {Dosage }}\right.$ $=0.21$; Figure $3 \mathrm{~A})$. At d-3 postpartum, SCFP-fed cows tended to have lower NEFA concentrations than control cows (630 vs. $897 \mu \mathrm{Eq} / \mathrm{L} ; P=0.06)$ and cows receiving $112 \mathrm{~g}$ of $\mathrm{SCFP} / \mathrm{d}$ had higher BHBA concentrations than cows fed $56 \mathrm{~g}$ of SCFP/d (1.04 vs. $0.78 \mathrm{mmol} / \mathrm{L}$; $P=0.05)$. Prepartal BCS tended to be higher in cows receiving 112 versus $56 \mathrm{~g}$ of $\mathrm{SCFP} / \mathrm{d}(P=0.06)$, with differences being small but statistically significant at 3 wk prepartum (3.66 vs. $3.51 ; P=0.01$; Figure $3 \mathrm{C}$ ).

\section{Effect of SCFP Supplementation and Dosage on Indicators of Immune Status}

Overall, SCFP supplementation and dosage did not affect the serum concentrations of SAA ( $P_{\text {Supplementation }}$ $=0.61 ; P_{\text {Dosage }}=0.73 ;$ Figure $\left.4 \mathrm{~A}\right)$ and haptoglobin $\left(P_{\text {Supplementation }}=0.82 ; P_{\text {Dosage }}=0.15 ;\right.$ Figure $\left.4 \mathrm{~B}\right)$. As SAA and haptoglobin concentrations are elevated in the first week after calving (Humblet et al., 2006) and during the last week preceding disease diagnosis (Sabedra et al., 2012), we specifically focused on the last week before and the first week after calving. The last day before calving, SCFP-fed cows had or tended to have lower SAA $(15.6 \pm 3.5$ vs. $37.2 \pm 10.4 \mathrm{mg} / \mathrm{L}$; $P=0.02$; Figure $4 \mathrm{~A})$ and haptoglobin concentrations than control cows $(4.2 \pm 0.5$ vs. $6.1 \pm 1.1 \mathrm{mg} / \mathrm{L} ; P=$ 0.08; Figure 4B). Cows fed higher dosages of SCFP (112 vs. $56 \mathrm{~g} / \mathrm{d}$ ) had or tended to have lower haptoglobin concentrations prepartum $(3.41 \pm 0.28$ vs. $4.23 \pm$ $0.39 \mathrm{mg} / \mathrm{L} ; P=0.03)$ and during the last week before calving $(3.41 \pm 0.35$ vs. $4.47 \pm 0.49 \mathrm{mg} / \mathrm{L} ; P=0.06)$.

During the first week after calving, SCFP-fed cows had higher SAA concentrations than control cows (178 \pm 33 vs. $81 \pm 22 \mathrm{mg} / \mathrm{L} ; P=0.02)$, which was significant on the day after calving $(256 \pm 56$ vs. $103 \pm 32$ $\mathrm{mg} / \mathrm{L} ; P=0.02$ : Figure $4 \mathrm{~B})$. Similar but nonsignificant group differences were observed during the first week postpartum for haptoglobin concentrations. Outside the immediate peripartal period, no SCFP-supplementation effects on SAA and haptoglobin concentrations were observed (Figures $4 \mathrm{~A}$ and $4 \mathrm{~B}$ ).

Overall, SCFP supplementation and dosage did not affect the serum concentrations of IgG $\left(P_{\text {Supplementation }}=\right.$ $0.49 ; P_{\text {Dosage }}=0.58 ;$ Figure $\left.5 \mathrm{~A}\right), \operatorname{IgM}\left(P_{\text {Supplementation }}=\right.$ $0.62 ; P_{\text {Dosage }}=0.47 ;$ Figure $\left.5 \mathrm{~B}\right)$, and $\operatorname{IgA}\left(P_{\text {Supplementation }}\right.$ $=0.52 ; P_{\text {Dosage }}=0.14 ;$ Figure $\left.5 \mathrm{C}\right)$. The only significant group differences at any specific time point were observed in cows fed higher dosages of SCFP (112 vs. 56 $\mathrm{g} / \mathrm{d})$, with lower $\operatorname{IgA}$ concentrations at $\mathrm{d}-14(0.227$ \pm 0.012 vs. $0.272 \pm 0.011 \mathrm{~g} / \mathrm{L} ; P=0.01)$ and $\mathrm{d}-7$ postpartum $(0.218 \pm 0.016$ vs. $0.260 \pm 0.013 \mathrm{~g} / \mathrm{L} ; P=$ 0.05; Figure 5C). 
A)

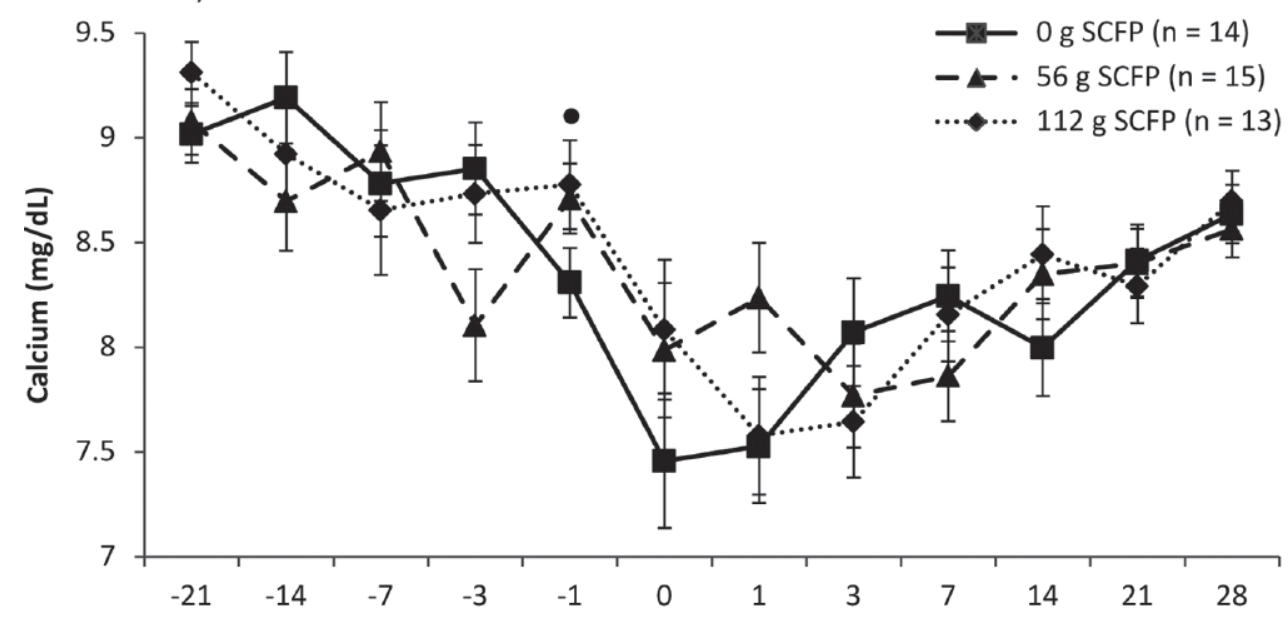

B)

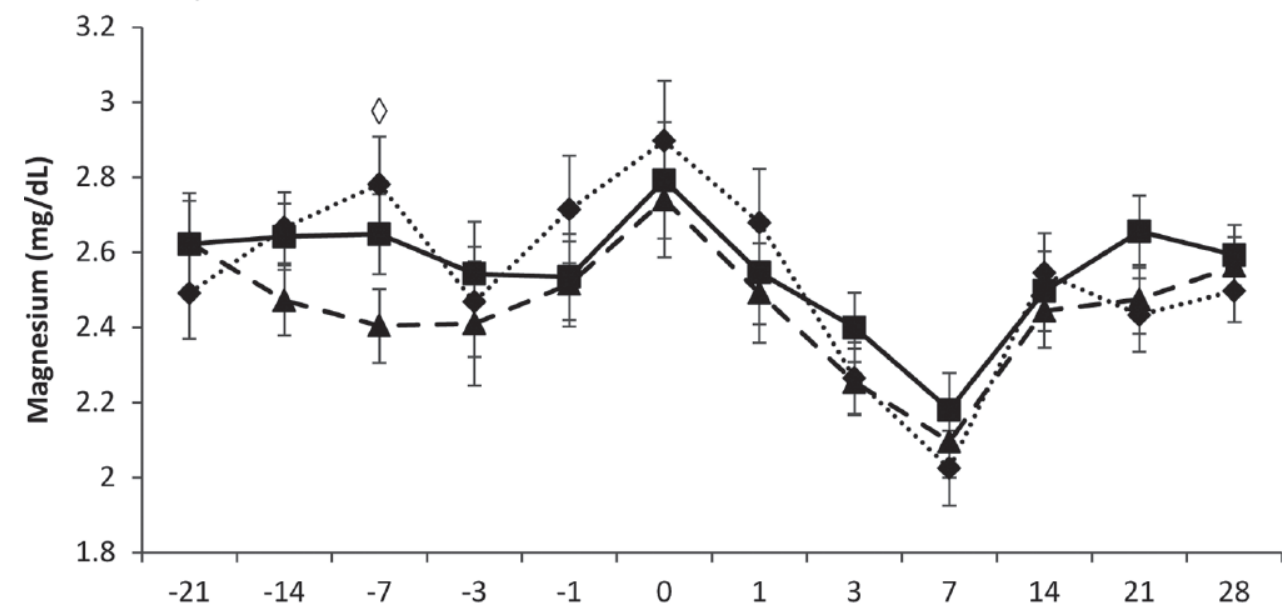

C)

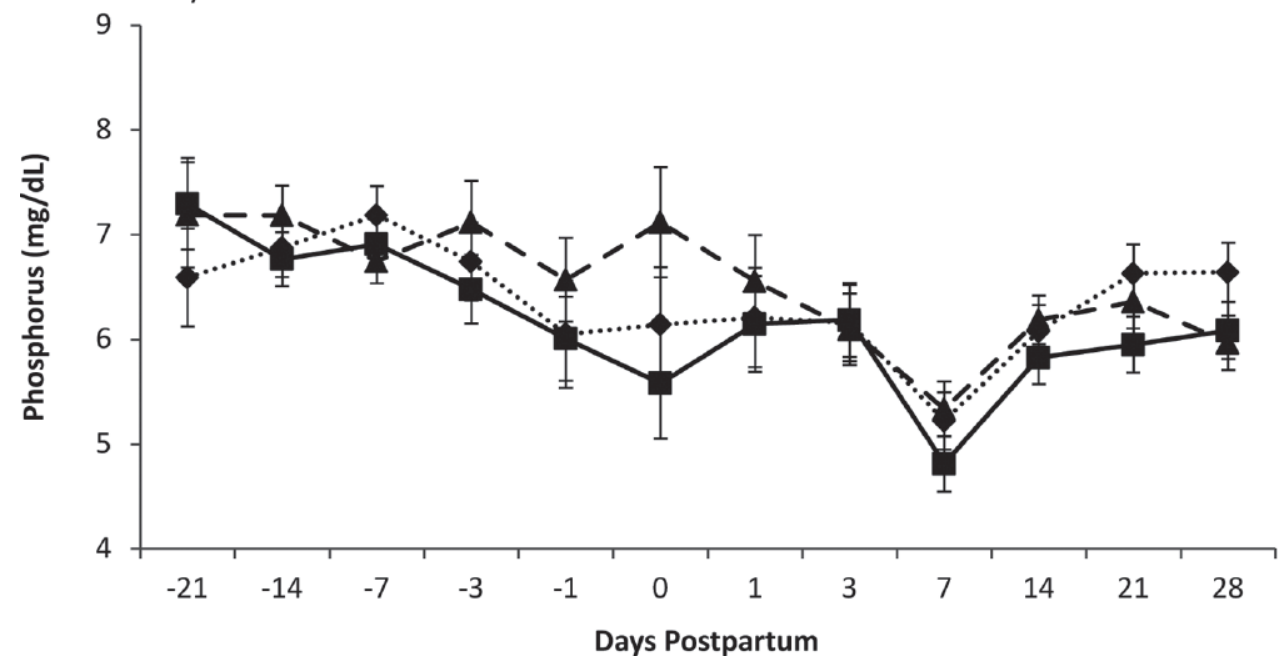

Figure 1. Effect of feeding various dosages of Saccharomyces cerevisiae fermentation product (SCFP; 0, 56, or 112 g of SCFP/d) to transition dairy cows on serum concentrations of (A) calcium, (B) magnesium, and (C) phosphorus. $\boldsymbol{\bullet}$ = Differences $(P \leq 0.05)$ between SCFP-fed $(56$ and $112 \mathrm{~g}$ of SCFP/d combined) versus control cows; $\diamond=$ differences $(P \leq 0.05)$ between 112 versus $56 \mathrm{~g} / \mathrm{d}$ SCFP-fed cows. Data are presented as LSM and SEM. 


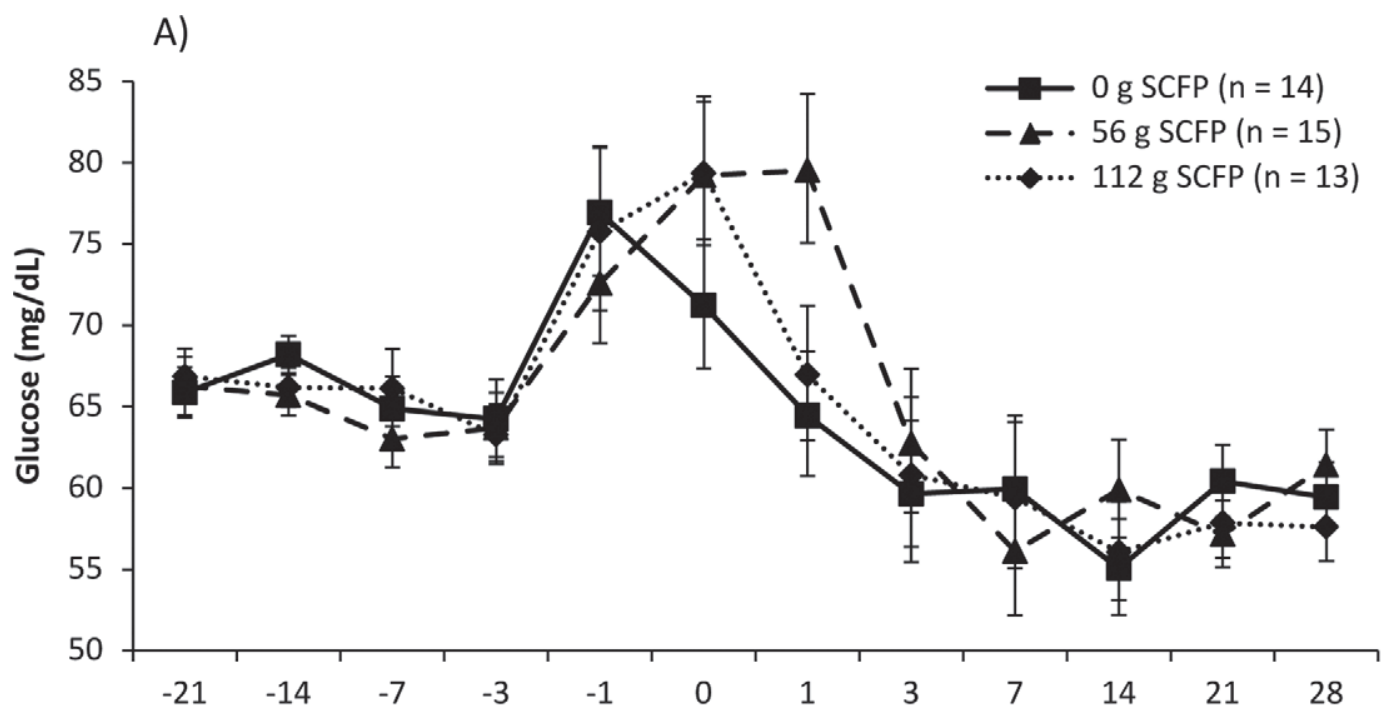

B)

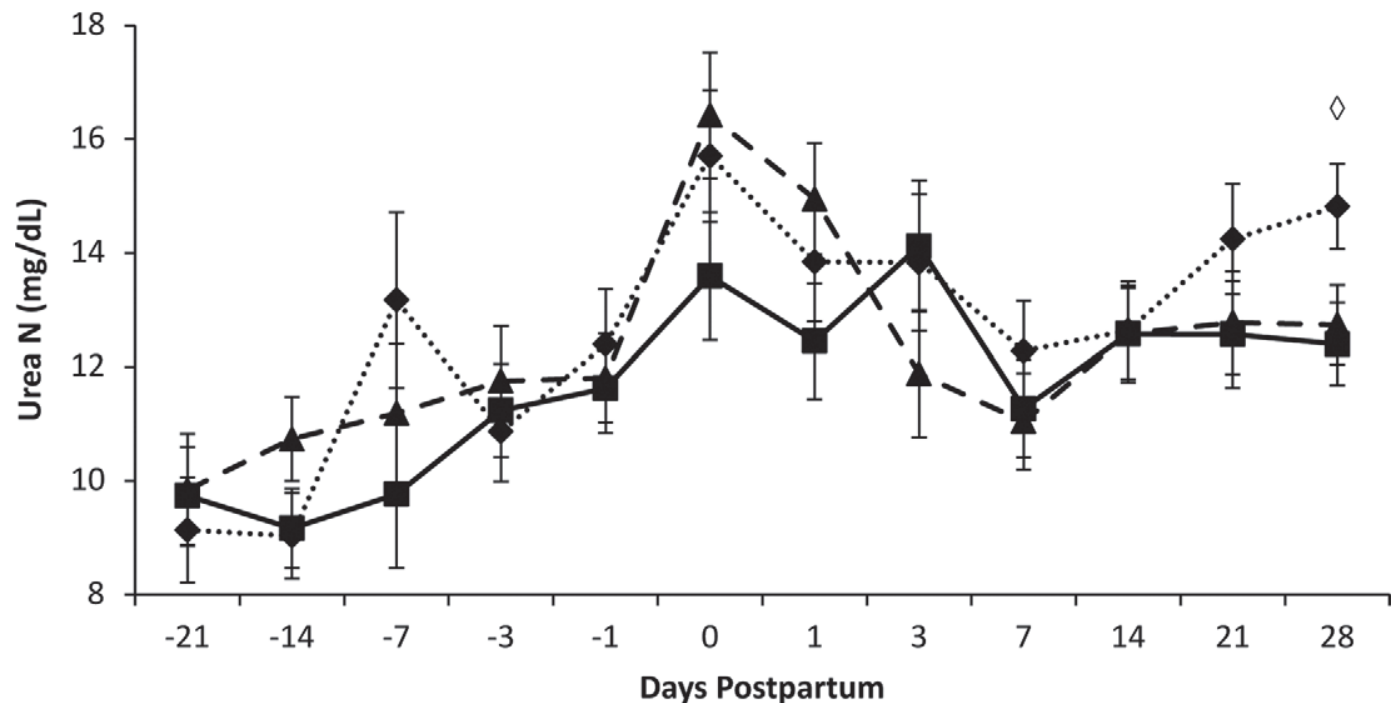

Figure 2. Effect of feeding various dosages of Saccharomyces cerevisiae fermentation product (SCFP; 0, 56, or 112 g of SCFP/d) to transition dairy cows on serum concentrations of $(\mathrm{A})$ glucose and $(\mathrm{B})$ urea $\mathrm{N}$. $\diamond=$ Differences $(P \leq 0.05)$ between 112 versus $56 \mathrm{~g} / \mathrm{d}$ SCFP-fed cows. Data are presented as LSM and SEM.

\section{Effect of SCFP Supplementation and Dosage on Hormone Concentrations}

Insulin concentrations were very low and not significantly affected by SCFP supplementation or dosage overall $\left(P_{\text {Supplementation }}=0.40 ; P_{\text {Dosage }}=0.73\right)$ or during the first $48 \mathrm{~h}$ after calving $\left(P_{\text {Supplementation }}=0.23 ; P_{\text {Dosage }}\right.$ $=0.82$; Figure $6 \mathrm{~A})$. Overall, SCFP-fed cows tended to have dosage-independently $(P=0.80)$ lower cortisol concentrations than control cows $(1.19 \pm 0.13$ vs. 1.90 $\pm 0.31 \mathrm{ng} / \mathrm{mL} ; P=0.02)$, which was significant for the postpartal period $(0.68 \pm 0.10 \mathrm{ng} / \mathrm{mL}$ vs. $1.37 \pm 0.29$ $\mathrm{ng} / \mathrm{mL} ; P=0.007)$ and specifically for $\mathrm{d} 1(P=0.02)$ and $\mathrm{d} 3(P=0.006)$ postpartum (Figure $6 \mathrm{~B})$.

\section{DISCUSSION}

Increased interest exists in feeding ruminal fermentation modifiers during the transition period to increase DMI and maximize nutrient utilization and thereby improve milk production as well as decrease the risk of infectious and metabolic disorders and reproductive failure (Eastridge, 2006). The fermentation modifier used in this study consisted of the fermentation metabolites produced from S. cerevisiae when grown using a proprietary technique, along with the fermentation medium (ground yellow corn, hominy feed, corn gluten feed, wheat middlings, rye middlings, diastatic malt and corn syrup, and cane molasses) used in the 
A)

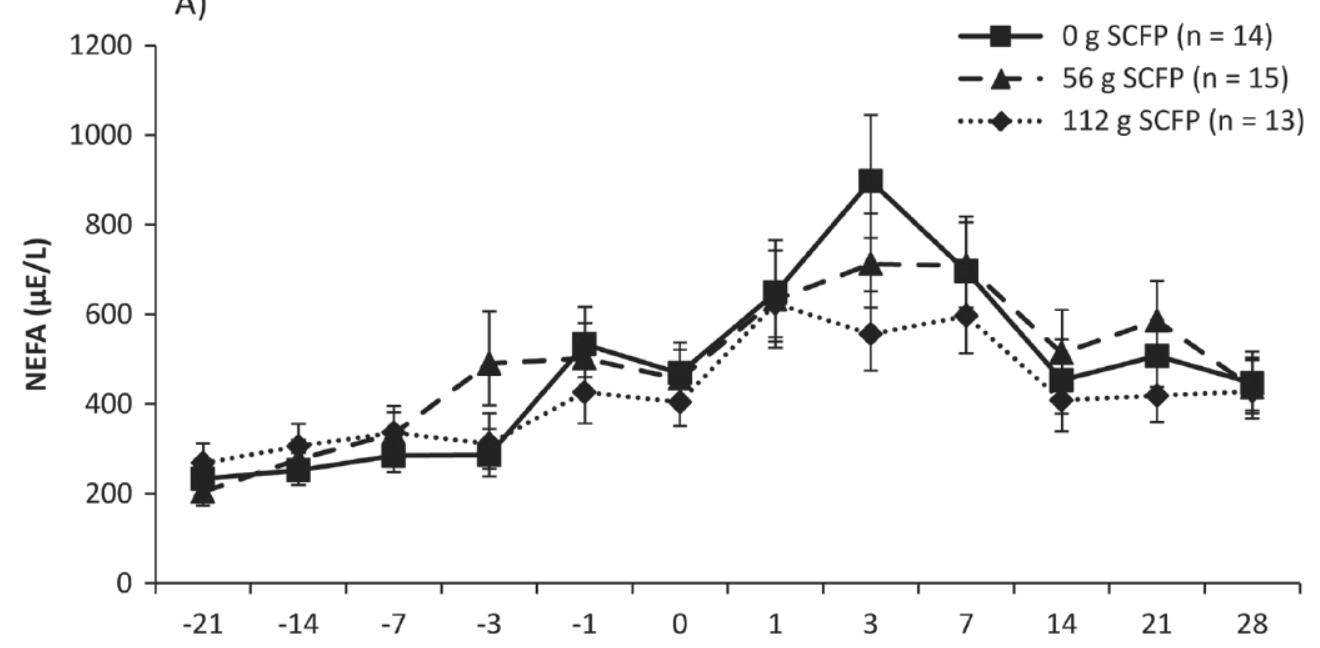

B)

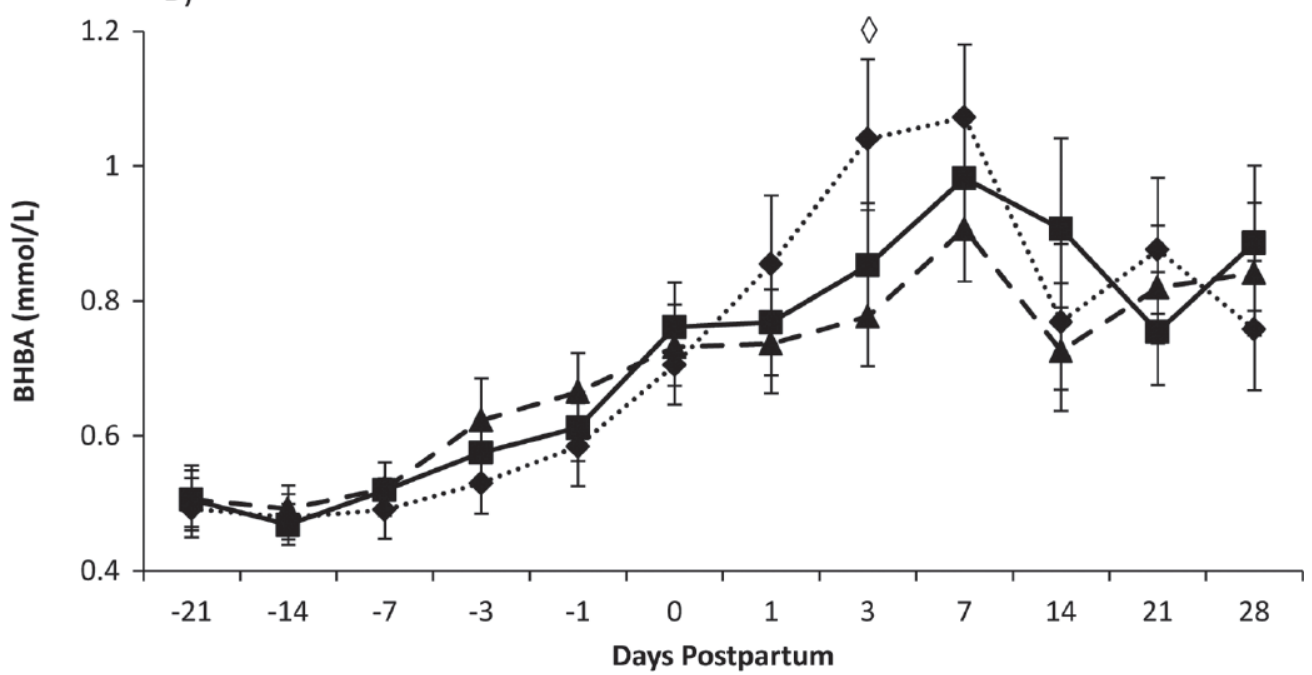

C) $\diamond$

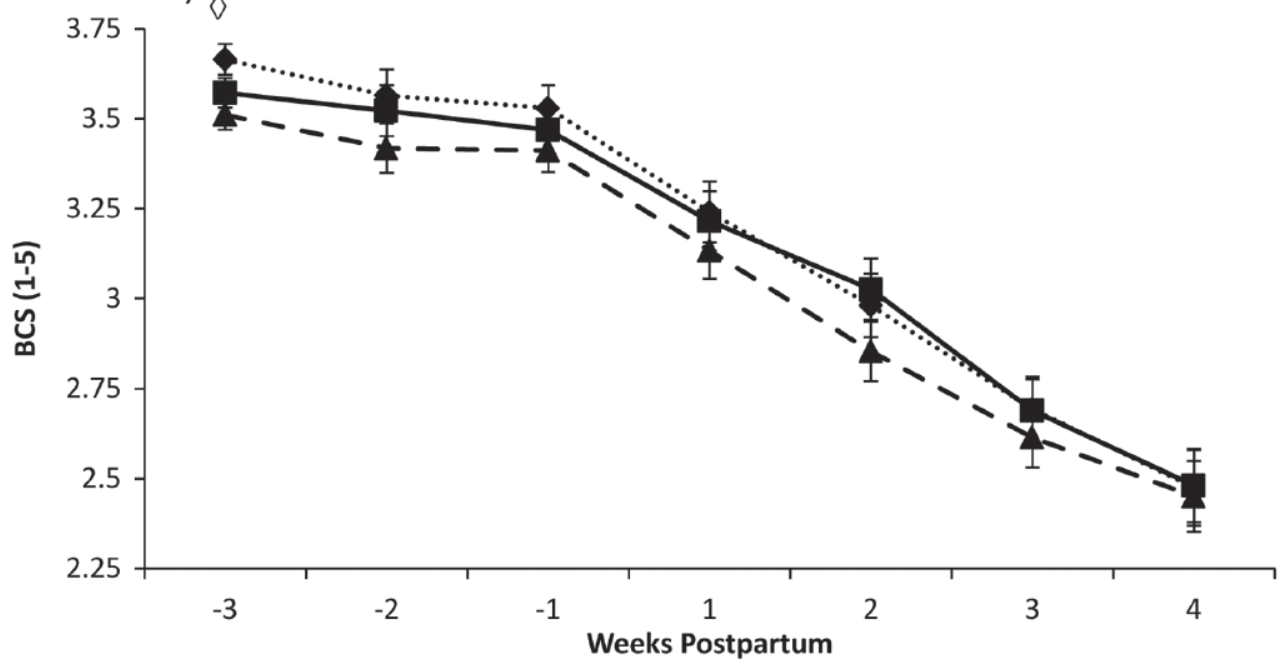

Figure 3. Effect of feeding various dosages of Saccharomyces cerevisiae fermentation product (SCFP; 0, 56, or $112 \mathrm{~g}$ of SCFP/d) to transition dairy cows on serum concentrations of (A) NEFA, (B) BHBA, and (C) BCS. $\diamond=$ Differences $(P \leq 0.05)$ between 112 versus $56 \mathrm{~g} / \mathrm{d}$ SCFP-fed cows. Data are presented as LSM and SEM. 


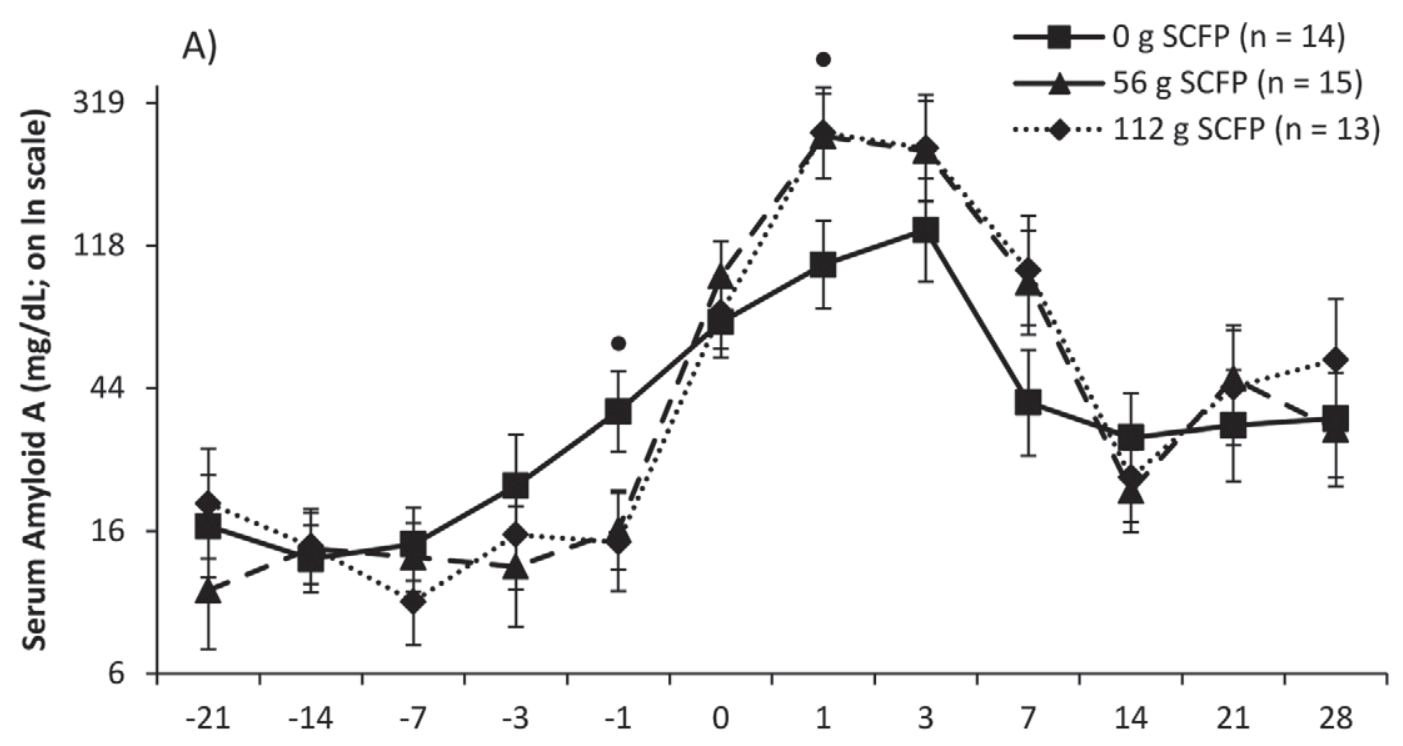

B)

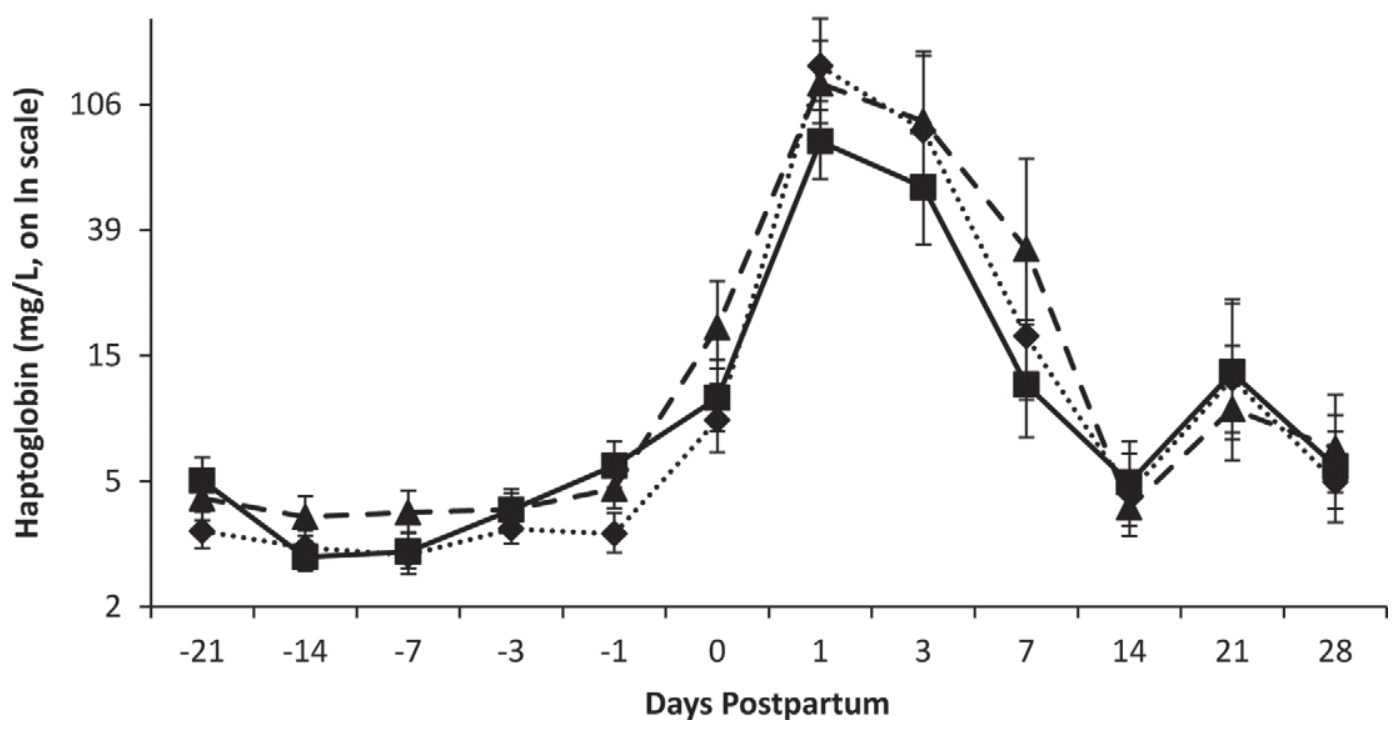

Figure 4. Effect of feeding various dosages of Saccharomyces cerevisiae fermentation product (SCFP; 0, 56, or 112 g of SCFP/d) to transition dairy cows on serum concentrations of (A) serum amyloid A and (B) haptoglobin. Data are displayed on a natural logarithmic scale. $\bullet$ Differences $(P \leq 0.05)$ between SCFP-fed (56 and $112 \mathrm{~g}$ of SCFP/d SCFP combined) versus control cows.

production process. This SCFP contains antioxidants, $\mathrm{B}$ vitamins, nucleotides, amino acids, soluble fiber, and other bioactive compounds that can serve as nutrient sources and growth promoters for rumen microflora (Callaway and Martin, 1997). The SCFP can promote in a dosage-dependent manner the growth of cellulolytic, proteolytic, and lactate-utilizing bacteria in the rumen (Harrison et al., 1988; Callaway and Martin, 1997), which, in turn, can increase ruminal DM and protein digestibility (Miller-Webster et al., 2002; Yoon and Stern, 1996) and concentrations of propionate or ammonia, or both (Harrison et al., 1988; Miller-Webster et al., 2002; Erasmus et al., 2005).

\section{Effect of SCFP Supplementation and Dosage on Supplement Intake, Milk Yield, and Milk Composition}

We could not measure DMI in this study; however, feeding 56 to $60 \mathrm{~g}$ of SCFP/d during the transition period generally increases DMI by approximately 2 to 5\% (Robinson and Garrett, 1999; Dann et al., 2000; 


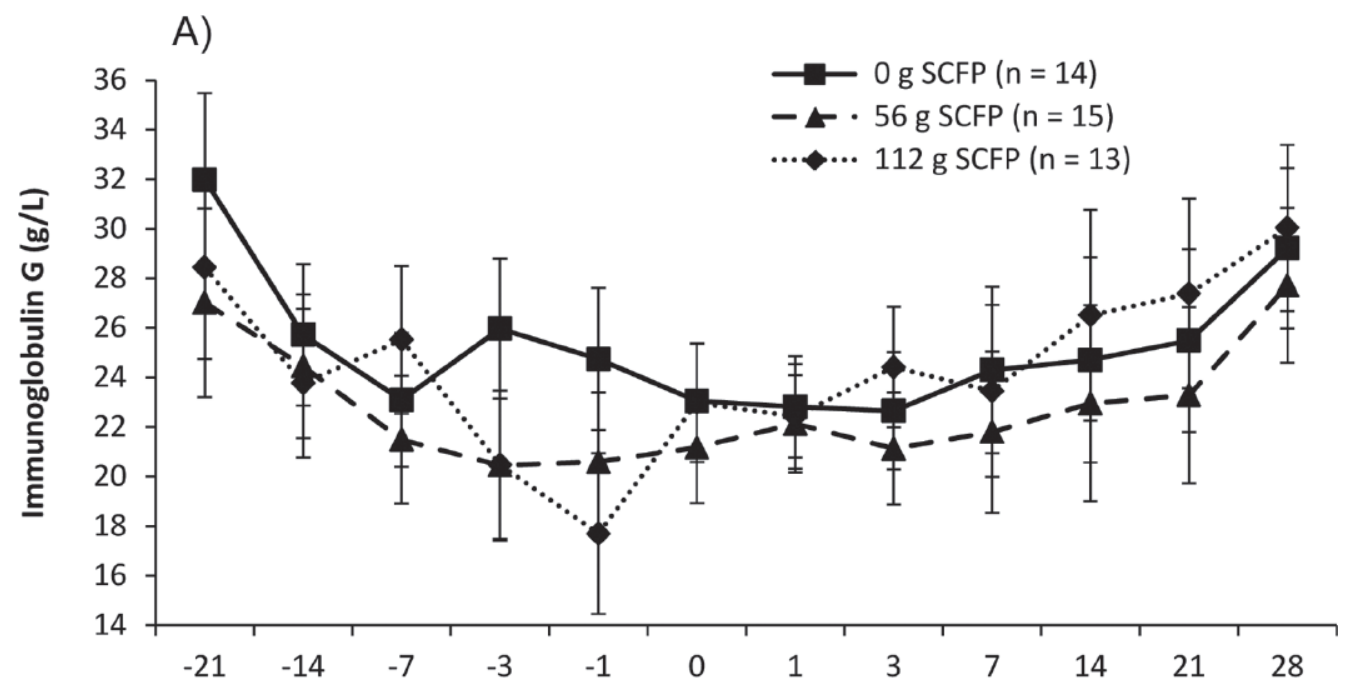

B)

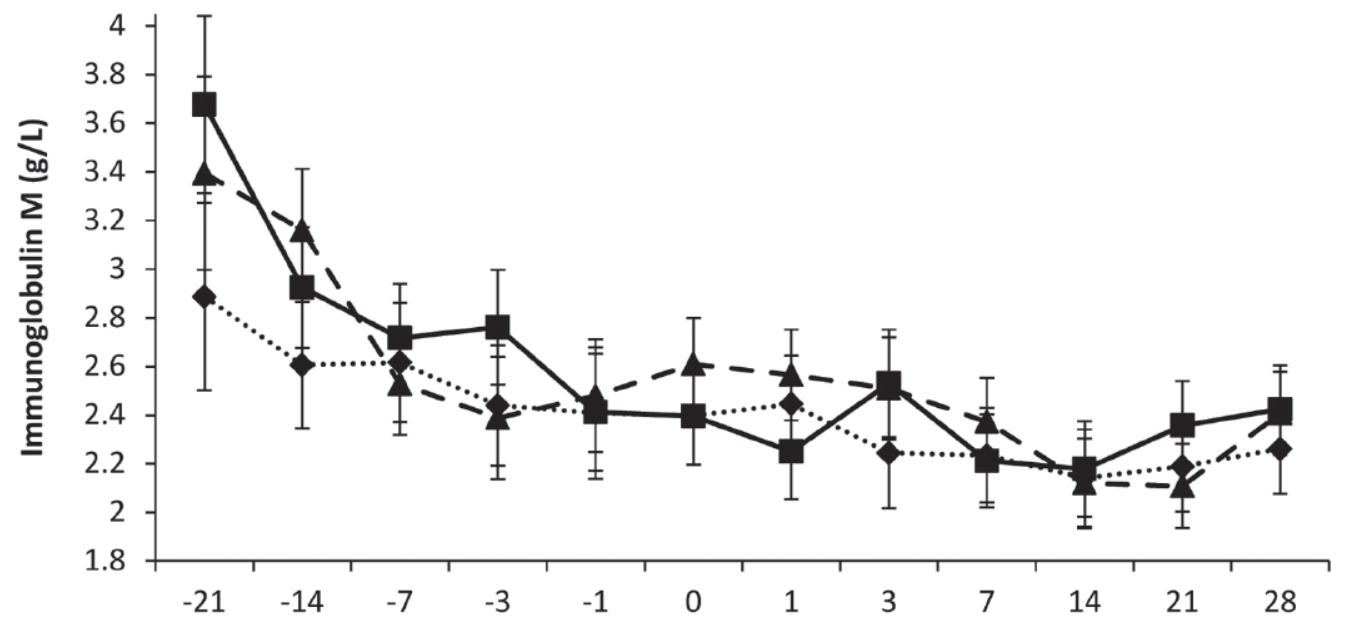

C)

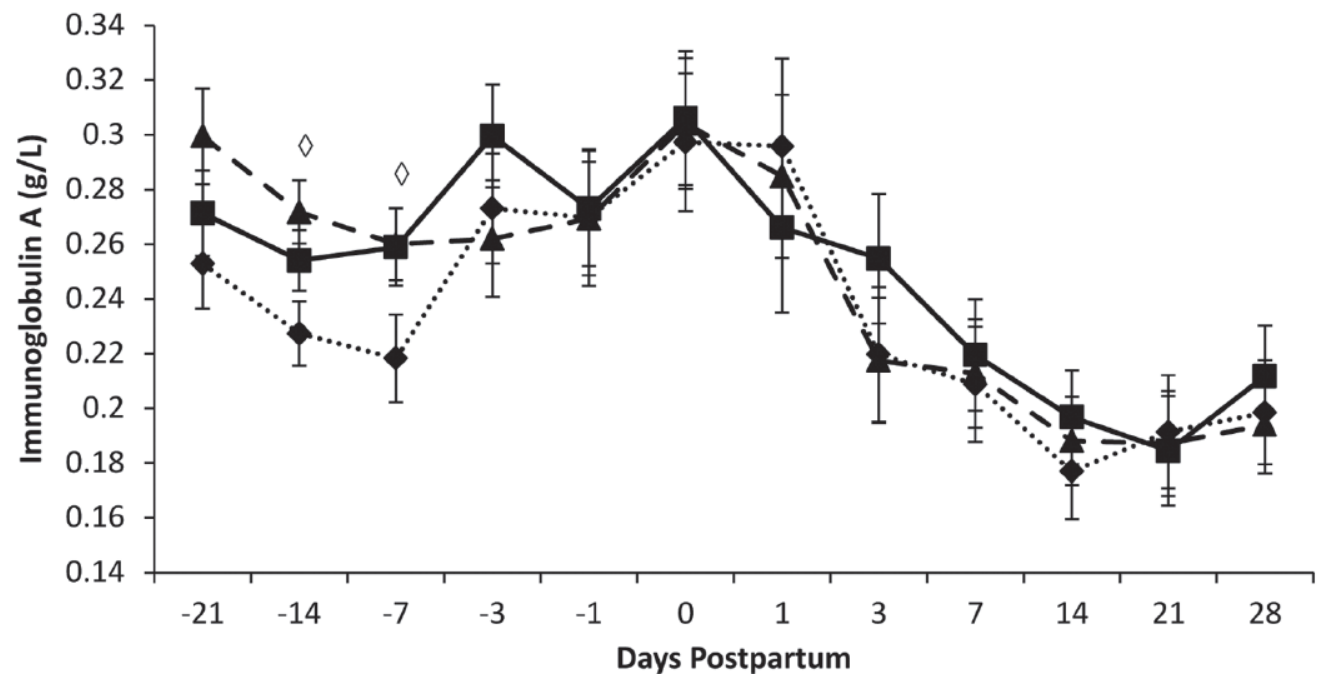

Figure 5. Effect of feeding various dosages of Saccharomyces cerevisiae fermentation product (SCFP; 0, 56, or $112 \mathrm{~g}$ of SCFP/d) to transition dairy cows on serum concentrations of $(\mathrm{A}) \operatorname{IgG},(\mathrm{B}) \operatorname{IgM}$, and $(\mathrm{C}) \operatorname{IgA}$. $\diamond=$ Differences $(P \leq 0.05)$ between 112 versus $56 \mathrm{~g} / \mathrm{d}$ SCFP-fed cows. 


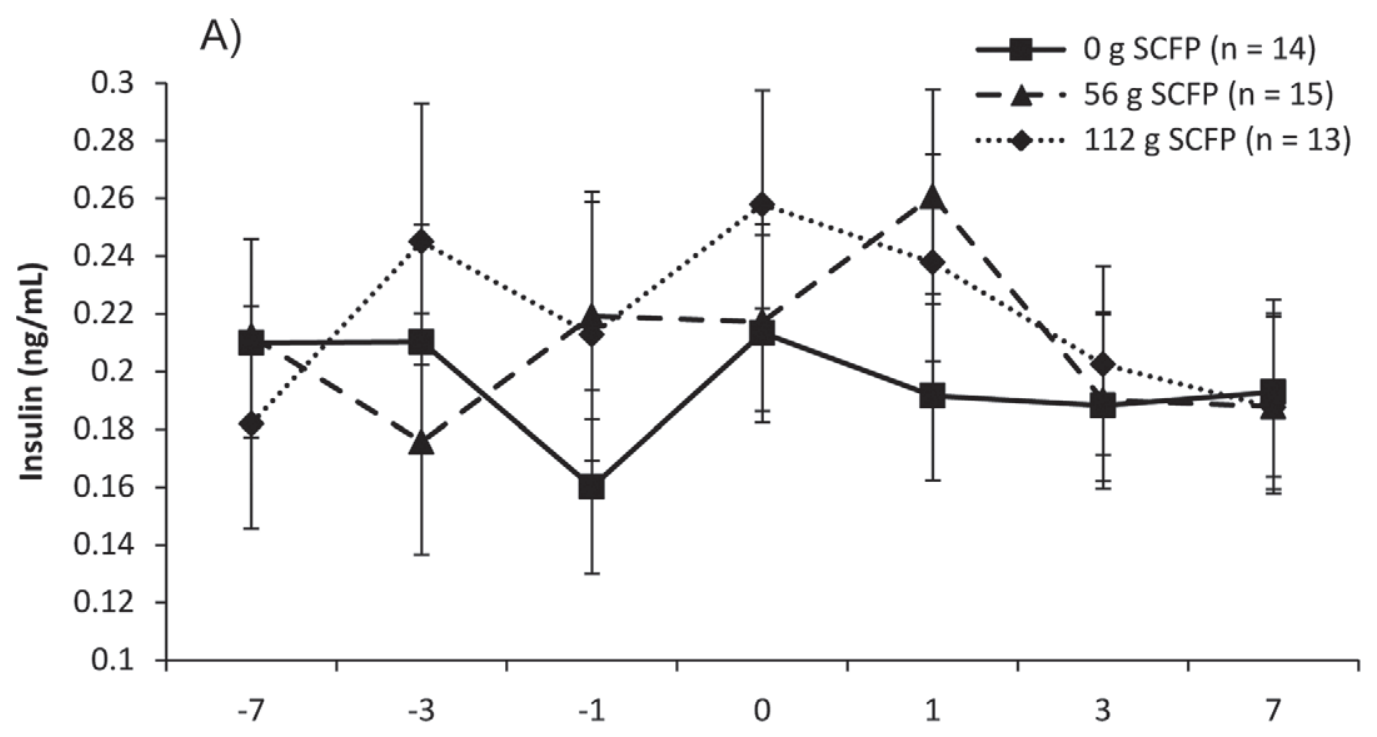

B)

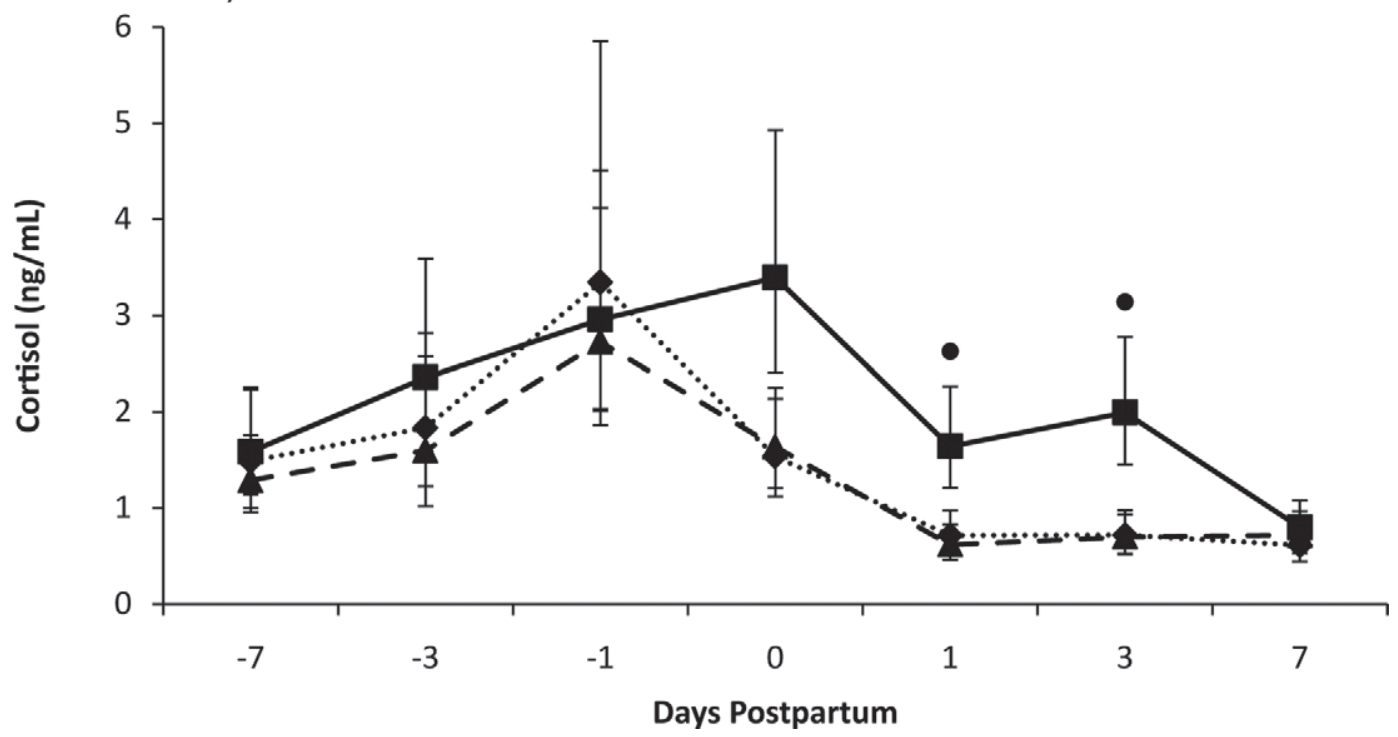

Figure 6. Effect of feeding various dosages of Saccharomyces cerevisiae fermentation product (SCFP; 0, 56, or 112 g of SCFP/d) to transition dairy cows on serum concentrations of $(\mathrm{A})$ insulin and (B) cortisol. $\bullet=$ Differences $(P \leq 0.05)$ between SCFP-fed (56 and $112 \mathrm{~g}$ of SCFP/d combined) versus control cows.

Ramsing et al., 2009). The highly palatable taste of SCFP may specifically promote feed intake at times when intake is low, such as around calving, or help cows adapt to the postpartal diet, which can explain why more SCFP-fed versus control cows finished their supplement on the morning after parturition. The beneficial effect of SCFP may be independent of its taste and caloric content, because the supplements contained equally high concentrations of liquid molasses (33\% of total supplement) and the amount of ground corn was adjusted to substitute for the amount of SCFP fed (Table 1). Cows prefer a sweet diet (Nombekela et al., 1994) and liquid molasses is sweet and improves feed intake of dairy cows (Broderick and Radloff, 2004; Firkins et al., 2008; DeVries and Gill, 2012). In the absence of taste and caloric differences of the supplements used in the current study, we hypothesize that SCFPassociated increases in feed intake of transition dairy cows are a result of improved ruminal DM and protein digestibility (Miller-Webster et al., 2002; Yoon and Stern, 1996). The effect of SCFP and other ruminal fermentation modifiers on DMI and ruminal digestibility in transition dairy cows warrants further study. Feeding 112 vs. $56 \mathrm{~g}$ of $\mathrm{SCFP} / \mathrm{d}$ did not significantly change 
supplement consumption, which is similar to our previous study in which 227 versus $57 \mathrm{~g}$ of SCFP/d did not significantly alter feed intake around calving (Ramsing et al., 2009), suggesting that feeding more than $56 \mathrm{~g}$ of $\mathrm{SCFP} / \mathrm{d}$ may not provide additional benefits for feed consumption. Alternatively, too few animals may have been included to detect a significant difference between the dosages used in this study.

Associated with increases in DMI, feeding 56 to $60 \mathrm{~g}$ of SCFP/d to transition dairy cows generally increases milk production by 2 to $5 \%$, on average (Robinson and Garrett, 1999; Dann et al., 2000; Ramsing et al., 2009). Consistent with the results of previous studies, milk production was increased in SCFP-supplemented versus control cows (Table 3), although the milking frequency in our study $(6 \times / d)$ was higher than in previous studies $(2 \times /$ d; Robinson and Garrett, 1999; Dann et al., 2000; Ramsing et al., 2009). In the absence of treatment differences in BCS postpartum and the parallel increase in milk production and DMI in previous SCFP-feeding studies of transition dairy cows (Robinson and Garrett, 1999; Dann et al., 2000; Ramsing et al., 2009), we attribute the SCFP-associated increases in milk production of early lactation cows to increased feed intake or increased dietary energy availability (Robinson and Garrett, 1999; Dann et al., 2000), or both. We previously reported no additional increases in DMI and milk production with feeding 227 versus $57 \mathrm{~g}$ of $\mathrm{SCFP} / \mathrm{d}$ (Ramsing et al., 2009), which is consistent with our results for milk production with feeding 112 versus $56 \mathrm{~g}$ of SCFP/d (Table 3).

Similar to previous SCFP-feeding studies in transition dairy cows (Robinson and Garrett, 1999; Dann et al., 2000; Ramsing et al., 2009), SCFP feeding did not affect milk component concentrations (Table 3). We, however, observed lower SCC in milk of SCFPfed versus control cows (Table 3), which had been previously observed in 1 study (Bluel, 2006) but not in other studies with SCFP supplementation (Dann et al., 2000; Ramsing et al., 2009). In cell culture, SCFP can activate natural killer cells, increase their cytotoxic response, and activate B lymphocytes (Jensen et al., 2008c), which may explain our results.

\section{Effect of SCFP Supplementation and Dosage on Macromineral Status}

One of the biggest challenges in dairy cows is to maintain adequate macromineral concentrations in blood when requirements for milk production dramatically increase after calving. The production of $10 \mathrm{~kg}$ of colostrum on the day of calving requires approximately $10.3 \mathrm{~g}$ of calcium, $5.4 \mathrm{~g}$ of phosphorus, and $0.2 \mathrm{~g}$ of magnesium, which have to be met by diet or mobiliza- tion from body tissues (Goff and Horst, 1997). Calcium concentrations in blood are tightly regulated in the range of 8 to $10 \mathrm{mg} / \mathrm{dL}$ (as reviewed by Goff, 2008). As calcium is essential in nerve, muscle, hormone, and hormone function, calcium below $8 \mathrm{mg} / \mathrm{dL}$, indicative of hypocalcemia, can decrease DMI, milk production, and immune function, and increase the risk of infectious and metabolic disorders, including mastitis (Kimura et al., 2006; Mulligan et al., 2006; Goff, 2008).

The results of our study suggest that feeding SCFP may help cows adapt to the increased calcium requirements after parturition. In support, fewer SCFP-fed versus control cows had serum concentrations below 8 $\mathrm{mg} / \mathrm{dL}$ during the first $48 \mathrm{~h}$ postpartum, a time period most sensitive to calcium imbalances. Control cows had lower serum calcium concentrations than SCFP-fed cows on the day before calving ( 8.31 vs. $8.74 \mathrm{mg} / \mathrm{dL}$; $P=0.05$; Figure $1 \mathrm{~A}$ ) and tended to have lower serum calcium concentrations during the first $48 \mathrm{~h}$ after calving. Treatment with CMPK solution after calving did not differ between treatment groups and, thus, cannot explain the observed differences in serum calcium concentrations. Future studies are warranted to determine whether the SCFP effects on serum calcium are caused by differences in DMI, nutrient absorption, calcium mobilization from body tissue, or a combination of those factors.

Magnesium is important for muscle and nerve function and its concentrations are tightly controlled in blood (as reviewed by Goff, 2008). As magnesium is well absorbed, magnesium requirements can be usually met by the diet, unless the diet has insufficient magnesium or ruminal absorption of magnesium is impaired (Goff, 2000). Serum magnesium concentrations are increased around calving, as increased requirements for calcium increase parathyroid hormone (Goff, 2000). Hypomagnesemia, indicated by plasma concentrations of below $1.8 \mathrm{mg} / \mathrm{dL}$, can decrease DMI and induce hypocalcemia (Goff, 2008). Serum magnesium concentrations were not affected by SCFP supplementation or dosage (Figure 1B), which is consistent with prior studies (Sanchez et al., 1997), indicating that SCFP supplementation does not affect magnesium status or balance nor contributed to the beneficial effect of SCFP supplementation on serum calcium.

Despite its importance for many physiological functions (ATP, phospholipids, and nucleic acids), phosphorus is not tightly regulated and varies in healthy cows between 4 and $8 \mathrm{mg} / \mathrm{dL}$ in plasma (as reviewed by Goff, 2000). Under most circumstances, blood phosphorus concentrations follow dietary concentrations and DMI (Goff, 2000). Serum phosphate concentrations decreased after parturition (Figure 1C) in response to the increased demands for milk production and salivary ex- 
cretions. Serum phosphorus concentrations were higher in SCFP-fed versus control cows after calving, with the largest differences in phosphorus concentrations being observed directly after calving (6.63 vs. $5.58 \mathrm{mg} / \mathrm{dL}$; Figure 1C). Our results are consistent with a previous study, in which serum phosphorus concentrations were higher in SCFP-fed versus control cows during the first 13 wk of lactation (6.67 vs. $5.61 \mathrm{mg} / \mathrm{dL}$; Sanchez et al., 1997). Saccharomyces cerevisiae fermentation product feeding may increase feed intake or dietary phosphorus absorption, or both. Rumen microbiota play an important role for dietary phosphorus absorption, as a significant proportion of plant-bound phosphorus is in the form of phytate, which cannot be absorbed unless being metabolized by the gut microbiota (Goff, 2000). Future studies are warranted to examine whether SCFP specifically alters phytate digestion or whether the higher phosphorus concentrations are caused by a general SCFP effect on DMI or digestion, or both (Miller-Webster et al., 2002).

\section{Effect of SCFP Supplementation and Dosage on Nutrient and Energy Status}

A big challenge for dairy cows is to adapt to the increased nutrient and energy requirements after parturition (Overton and Waldron, 2004). The production of $10 \mathrm{~kg}$ of colostrum on the day of calving approximately requires $11 \mathrm{Mcal}$ of energy (Goff and Horst, 1997), 1,000 $\mathrm{g}$ of protein (assuming 10\% protein concentration), and $411 \mathrm{~g}$ of glucose (assuming a 3\% lactose concentration and $73 \%$ conversion efficiency of glucose to lactose). Besides being used for lactose, glucose is essential for many physiological processes (Bell and Bauman, 1997). The primary precursors for hepatic glucose synthesis in early lactation are propionate synthesized from the microbiome, gluconeogenic AA from diet or body tissue mobilization, lactate, and glycerol (Ingvartsen, 2006). To facilitate glucose synthesis, gluconeogenesis, and ureagenesis, the end product of which is urea $\mathrm{N}$, are coordinately regulated by hormones (promoted by glucagon and cortisol and inhibited by insulin; Bell and Bauman, 1997; Bobe et al., 2009). In the peripartal period, we observed an increase in serum glucose and urea $\mathrm{N}$ concentrations (Figure 2), which can reflect body protein mobilization and elevated cortisol concentrations around calving (Bell and Baumann, 1997; Ingvartsen and Andersen, 2000). After the peripartal period, serum urea $\mathrm{N}$ concentrations reflect under most conditions dietary supply of their precursors (Colmenero and Broderick, 2006), whereas glucose concentrations are also influenced strongly by hormones (Bell and Bauman, 1997).
Results in the current study suggest that SCFP may accelerate adaptation to the postpartal diet and its nutrient utilization. In support, SCFP-feeding tended to increase serum glucose and urea $\mathrm{N}$ concentrations during the first $48 \mathrm{~h}$ after calving (Figure 2), the same time when SCFP-feeding tended to increase serum calcium concentrations (Figure 1A). Previous studies showed that SCFP improves ruminal DM and protein digestibility (Yoon and Stern, 1996; Miller-Webster et al., 2002), resulting in higher concentrations of propionate or ammonia, or both (Harrison et al., 1988; MillerWebster et al., 2002; Erasmus et al., 2005).

To meet the increased energy requirements for milk production after parturition, dairy cows rely heavily on mobilization of triacylglycerols from adipose tissue, resulting in a rapid decline in BW and BCS (Bobe et al., 2004). The mobilized triacylglycerols are released into the blood stream as glycerol and NEFA (Drackley, 1999). Thus, circulating NEFA concentrations indicate the degree of lipid mobilization. Although NEFA are important energy sources and precursors for milk fat synthesis, at very high concentrations NEFA become a liability for liver function, as NEFA have to be either repackaged and transported out of the liver, stored in the liver as triacylglycerols, or oxidized (Bobe et al., 2004). In early lactation, however, oxidation of acetyl-CoA that originated from $\beta$-oxidation of NEFA is limited, as gluconeogenesis and the tricarboxylic acid cycle both compete for mitochondrial oxaloacetate (Bobe et al., 2009). As an alternative route, BHBA is synthesized from incompletely oxidized FA and can be used also as energy fuel, but is, at sufficiently high concentrations, detrimental to the immune and metabolic function, increasing the risk of infectious and metabolic disorders (Bobe et al., 2004; Ingvartsen and Moyes, 2013). Lipid mobilization is regulated by hormones, with cortisol and glucagon in the short term increasing lipid mobilization and insulin decreasing it (Bobe et al., 2004).

Serum NEFA and BHBA concentrations were elevated in early lactation, whereas BCS decreased rapidly (Figure 3), indicating strong lipid mobilization. Supplementation with 56 or $112 \mathrm{~g}$ of SCFP/d did not significantly alter BCS and serum NEFA and BHBA concentrations during the first $4 \mathrm{wk}$ postpartum. Similarly, supplementation with 57 or $227 \mathrm{~g}$ of SCFP/d did not affect serum NEFA and BHBA concentrations and BW in transition dairy cows (Robinson and Garrett, 1999; Ramsing et al., 2009) or BCS (Robinson and Garrett, 1999). Taking into account the higher milk production in SCFP-fed versus control cows in our study and others (Robinson and Garrett, 1999; Ramsing et al., 2009), the results suggest that SCFP-supplementation dosage independently improves dietary energy utilization or 
absorption (Robinson and Garrett, 1999; Dann et al., 2000), which may or may not be DMI dependent.

Dann et al. (2000) reported that feeding $60 \mathrm{~g}$ of $\mathrm{SCFP} / \mathrm{d}$ to Jersey cows decreased BW loss during the first 6 wk of lactation; those effects could not be detected with BCS or BW loss during the first 3 wk of lactation, as control cows continued to lose BW between wk 3 and 6 of lactation, whereas SCFP-fed cows started to gain $\mathrm{BW}$. We observed a similar trend for BCS between wk 4 and 7 of lactation, although cows were not SCFP supplemented between wk 4 and 7 of lactation (ShriverMunsch et al., 2011). Thus, we hypothesize that SCFP supplementation may be beneficial for shortening the postpartal negative energy status period, which warrants further study.

\section{Effect of SCFP Supplementation and Dosage on Immune Status}

The immune system has 2 functional units: the nonspecific or innate immune system and the specific or adaptive immune system. The first reaction of the body to infection, tissue injury or trauma, or stress is nonspecific and includes inflammation and production of positive acute-phase proteins. The major positive acute-phase proteins in dairy cattle are haptoglobin and SAA (Cray et al., 2009), the production of which is induced by proinflammatory cytokines, specifically tumor necrosis factor $\alpha$ and IL-6, and glucocorticoids including cortisol (Higuchi et al., 1994; Yoshioka et al., 2002), and inhibited by insulin (Wallerstedt et al., 2011). Compared with haptoglobin, SAA is less specific and faster in its response to cytokines and glucocorticoids in bovine hepatocytes (Alsemgeest et al., 1996), a primary, but not only, site of haptoglobin and SAA synthesis (Ceciliani et al., 2012; Lecchi et al., 2012). Consistent with our results (Figure 4), haptoglobin and SAA are elevated in the first week postpartum (Humblet et al., 2006), whereas the inflammatory response appears to be suppressed during the last week before calving (Quesnell et al., 2012).

The results of our study suggest that SCFP feeding can induce the nonspecific immune system after parturition. In support, SAA concentrations were greater in SCFP-fed versus control cows in the first week after calving (178 vs. $81 \mathrm{mg} / \mathrm{L} ; P=0.02$ ). Haptoglobin concentrations followed similar trends as SAA (Figure 4) but were not significantly affected. Faster adaptation to the postpartal diet or improved nutrient and energy utilization, absorption, or both in SCFP-fed versus control cows (Robinson and Garrett, 1999; Dann et al., 2000) may have increased the innate immune response, as improved nutrient and energy status improves in- nate immune responses (as reviewed by Ingvartsen and Moyes, 2013).

In contrast to the results in the first week postpartum, serum SAA concentrations tended to be lower in SCFP-fed versus control cows in the last week prepartum (14 vs. $23 \mathrm{mg} / \mathrm{L} ; P=0.06$ ). Similarly, SCFP feeding showed antiinflammatory properties in rats (Evans et al., 2012). In cell culture, SCFP had both stimulatory and inhibitory effects on the innate immune response, increasing natural killer cell killing but also inhibiting neutrophil reactive oxygen species formation and IFN- $\gamma$ production and inhibiting the growth of pathogens (Jensen et al. 2007, 2008 b,c).

The question arises whether an increase or decrease in haptoglobin and SAA concentrations is desirable. Elevated haptoglobin and SAA concentrations are recognized as indicators of metabolic and infectious diseases in dairy cows (Ametaj et al., 2011). We previously showed that persistent, elevated haptoglobin concentrations during the first week after calving are positively associated with incidence and severity of diseases during early lactation and that elevated haptoglobin concentrations precede clinical disease onset and, thus, may serve as an indicator of subclinical health problems (Sabedra et al., 2012); however, such observational data do not prove that elevated haptoglobin concentrations cause diseases. In fact, elevated SAA and haptoglobin concentrations for a short time can be protective against diseases, as SAA and haptoglobin promote the first phase of the nonspecific immune response. Haptoglobin and SAA in particular can act as a chemoattractant and induce migration, adhesion, and tissue infiltration of leukocytes (Badolato et al., 1994; Xu et al., 1995; Maffei et al., 2009) and both have antimicrobial properties (Delanghe et al., 1998; Badolato et al., 2000). Haptoglobin and SAA can act as a negative feedback loop and downregulate cytokine-induced inflammation (Shainkin-Kestenbaum et al., 1991; Arredouani et al., 2005). Furthermore, suppression of inflammation during the first week after calving may inhibit metabolic adaptations to the increased nutrient requirements for lactation (Farney et al., 2013). Thus, stimulation of haptoglobin and SAA by dietary components, such as SCFP, during the first week after calving, may be beneficial, given the absence of confounding disease situations. Future studies are warranted to examine the effect of SCFP feeding on the various components of the innate immune response in transition dairy cows.

During the last phase of the immune response, B lymphocytes synthesize antibodies (immunoglobulins) that are specific to the pathogen, which aid in the recognition and killing of pathogens by complement proteins and 
phagocytic cells (Butler, 1998). The primary immunoglobulins in blood are $\operatorname{IgG}$, usually separated into $\operatorname{IgG}_{1}$ and $\operatorname{IgG}_{2}$, IgM, and $\operatorname{IgA}$, constituting approximately 90, 9, and $1 \%$ of the total immunoglobulins (Butler, 1983; Burton et al., 1991). The 3 immunoglobulins have distinct functions and properties: IgA is the primary immunoglobulin in exocrine tracts such as the gastrointestinal mucosal wall, where IgA acts as local immune defense, agglutinating pathogens and interfering with bacterial adhesion and having antiinflammatory properties (Butler, 1983, 1998; Mantis et al., 2011). The other 2 immunoglobulins bind to the antigen and activate complement proteins for the killing of pathogens, with IgM more than 10 times as efficient in binding pathogens as IgG (Butler, 1983, 1998).

During the peripartal period, significant amounts of all 3 immunoglobulins are secreted into the colostrum (Butler, 1983; 1998), resulting in a decrease in their concentrations in blood (Guidry et al., 1980; Detilleux et al., 1995; Nonnecke et al., 2003), as observed in our study (Figure 5). In contrast to IgG, IgM and IgA remained lower in early lactation versus prepartum, consistent with other studies (Guidry et al., 1980; Detilleux et al., 1995), as IgM synthesis is decreased in the peripartal period (Detilleux et al., 1995; Nonnecke et al., 2003). Elevated NEFA, BHBA, and glucocorticoid concentrations may inhibit IgM production (Nonnecke et al., 1992, 1997; Lacetera et al., 2005).

In the current study, SCFP feeding did not affect IgG, IgM, or IgA concentrations (Figure 5). Similarly, SCFP consumption did not affect serum IgG and IgA concentrations in humans (Jensen et al., 2008a). To our knowledge, the effect of feeding SCFP on immunoglobulin synthesis has not been examined in cattle. In cell culture, SCFP feeding activates B lymphocytes (Jensen et al., 2007, 2008c). Lack of an immunoglobulin-induction protocol in our study may explain why we did not observe an effect of SCFP feeding on immunoglobulin concentrations. Future studies are warranted to examine the effects of SCFP feeding on the process of immunoglobulin synthesis.

\section{CONCLUSIONS}

Feeding SCFP during the transition period affected the metabolic and immunologic status of dairy cows in early lactation, as indicated by lower serum cortisol concentrations and at least a tendency to higher serum concentrations of calcium, glucose, urea $\mathrm{N}$, and SAA during the first day after calving, and higher phosphorus concentrations during the first 4 wk after calving. Higher SCFP dosages did not provide additional benefits in this study. Supplementation with SCFP may have a dosage-independent beneficial effect in supporting the physiologic adaptations after parturition, resulting in higher milk production and lower milk SCC. Further research is warranted to examine how feeding SCFP affects the feed intake and metabolic and immunologic status of transition dairy cows.

\section{ACKNOWLEDGMENTS}

This study was financially supported by the Linus Pauling Institute, Oregon State University (Corvallis), the Oregon State University Agricultural Research Foundation, the Oregon Beef Council (Portland, OR), the Eckelman graduate student scholarship, and a grant from Diamond V (Cedar Rapids, IA). The authors acknowledge the owners and staff of Van Beek Dairy (Monroe, OR) for use of their animals; B. Bledsoe, B. Block, B. Bronson, M. McGuire, P. Ramsing, A. Rudolph, D. Sabedra, C. Sause, and M. Swearingen (all in the Department of Animal and Rangeland Sciences, Oregon State University) for their assistance with supplement administration, sample collection, and data entry; M. Keller (Department of Animal and Rangeland Sciences, Oregon State University) for technical assistance; and L. Babcock and L. Webb (Willamette DHIA, Salem, OR) for assistance with milk sample collections.

\section{REFERENCES}

Alsemgeest, S. P. M., G. A. E. van 't Klooster, A. S. J. P. A. M. van Miert, C. K. Hulskamp-Koch, and E. Gruys. 1996. Primary bovine hepatocytes in the study of cytokine induced acute-phase protein secretion in vitro. Vet. Immunol. Immunopathol. 53:179-184.

Ametaj, B. N., A. Hosseini, J. F. Odhiambo, S. Iqbal, S. Sharma, Q. Deng, T. H. Lam, U. Farooq, Q. Zebeli, and S. M. Dunn. 2011. Application of acute phase proteins for monitoring inflammatory states in cattle. Chapter 13 in Acute Phase Proteins as Early NonSpecific Biomarkers of Human and Veterinary Diseases. F. Veas, ed. InTech, Rijeka, Croatia. Accessed Oct. 24, 2013. http://www. intechopen.com/articles/show/title/application-of-acute-phaseproteins-for-monitoring-inflammatory-states-in-cattle.

Arredouani, M. S., A. Kasran, J. A. Vanoirbeek, F. G. Berger, H. Baumann, and J. L. Ceuppens. 2005. Haptoglobin dampens endotoxin-induced inflammatory effects both in vitro and in vitro. Immunology 114:263-271.

Badolato, R., J. M. Wang, W. J. Murphy, A. R. Lloyd, D. F. Michiel, L. L. Bausserman, D. J. Kelvin, and J. J. Oppenheim. 1994. Serum amyloid $\mathrm{A}$ is a chemoattractant: Induction of migration, adhesion, and tissue infiltration of monocytes and polymorphonuclear leukocytes. J. Exp. Med. 180:203-209.

Badolato, R., J. M. Wang, S. L. Stornello, A. N. Ponzi, M. Duse, and T. Musso. 2000. Serum amyloid A is an activator of PMN antimicrobial functions: Induction of degranulation, phagocytosis, and enhancement of anti-Candida activity. J. Leukoc. Biol. $67: 381-386$.

Bell, A. W., and D. E. Bauman. 1997. Adaptations of glucose metabolism during pregnancy and lactation. J. Mamm. Gland Biol. Neoplasia 2:265-278.

Bluel, R. J. V. 2006. The effects of supplemental anionic salts and yeast culture on the production of dairy cattle during the periparturient period. MS Thesis. Univ. Missouri, Columbia. 
Bobe, G., J. C. Velez, D. C. Beitz, and S. S. Donkin. 2009. Glucagon increases hepatic mRNA concentrations of ureagenic and gluconeogenic enzymes in early-lactation dairy cows. J. Dairy Sci. 92:5092-5099.

Bobe, G., J. W. Young, and D. C. Beitz. 2004. Invited review: Pathology, etiology, prevention, and treatment of fatty liver in dairy cows. J. Dairy Sci. 87:3105-3124.

Broderick, G. A., and W. J. Radloff. 2004. Effect of molasses supplementation on the production of lactating dairy cows fed diets based on alfalfa and corn silage. J. Dairy Sci. 87:2997-3009.

Burton, J. L., B. W. McBride, B. W. Kennedy, J. H. Burton, T. H. Elsasser, and B. Woodward. 1991. Serum immunoglobulin profiles of dairy cows chronically treated with recombinant bovine somatotropin. J. Dairy Sci. 74:1589-1598.

Butler, J. E. 1983. Bovine immunoglobulins: An augmented review. Vet. Immunol. Immunopathol. 4:43-152.

Butler, J. E. 1998. Immunoglobulin diversity, B-cell and antibody repertoire development in large farm animals. Rev. Sci. Tech. 17:43-70.

Callaway, E. S., and S. A. Martin. 1997. Effects of a Saccharomyces cerevisiae culture on ruminal bacteria that utilize lactate and digest cellulose. J. Dairy Sci. 80:2035-2044.

Ceciliani, F., J. J. Ceron, P. D. Eckersall, and H. Sauerwein. 2012. Acute phase proteins in ruminants. J. Proteomics 75:4207-4231.

Colmenero, J. J. O., and G. A. Broderick. 2006. Effect of dietary crude protein concentration on milk production and nitrogen utilization in lactating dairy cows. J. Dairy Sci. 89:1704-1712.

Cray, C., J. Zaias, and N. H. Altman. 2009. Acute phase response in animals: A review. Comp. Med. 59:517-526.

Dann, H. M., J. K. Drackley, G. C. McCoy, M. F. Hutjens, and J. E. Garrett. 2000. Effects of yeast culture (Saccharomyces cerevisiae) on prepartum intake and postpartum intake and milk production of Jersey cows. J. Dairy Sci. 83:123-127.

Delanghe, J., M. Langlois, J. Ouyang, G. Claeys, M. De Buyzere, and B. Wuyts. 1998. Effect of haptoglobin phenotypes on growth of Streptococcus pyogenes. Clin. Chem. Lab. Med. 36:691-696.

Detilleux, J. C., M. E. Kehrli Jr., J. R. Stabel, A. E. Freeman, and D. H. Kelley. 1995. Study of immunological dysfunction in periparturient Holstein cattle selected for high and average milk production. Vet. Immunol. Immunopathol. 44:251-267.

DeVries, T. J., and R. M. Gill. 2012. Adding liquid feed to a total mixed ration reduces feed sorting behavior and improves productivity of lactating dairy cows. J. Dairy Sci. 95:2648-2655.

Drackley, J. K. 1999. Biology of dairy cows during the transition period: The final frontier? J. Dairy Sci. 82:2259-2273.

Eastridge, M. L. 2006. Major advances in dairy cattle nutrition. J. Dairy Sci. 89:1311-1323.

Edmonson, A. J., I. J. Lean, L. D. Weaver, T. Farver, and G. Webster. 1989. A body condition scoring chart for Holstein dairy cows. J. Dairy Sci. 72:68-78.

Erasmus, L. J., P. H. Robinson, A. Ahmadi, R. Hinders, and J. E. Garrett. 2005. Influence of prepartum and postpartum supplementation of a yeast culture and monensin, or both, on ruminal fermentation and performance of multiparous dairy cows. Anim. Feed Sci. Technol. 122:219-239.

Evans, M., S. Reeves, and L. E. Robinson. 2012. A dried yeast fermentate prevents and reduces inflammation in two separate experimental immune models. Evid. Based Complement. Alternat. Med. 2012:973041.

Farney, J. K., L. K. Mamedova, J. F. Coetzee, B. KuKanich, L. M. Sordillo, S. K. Stoakes, J. E. Minton, L. C. Hollis, and B. J. Bradford. 2013. Anti-inflammatory salicylate treatment alters the metabolic adaptations to lactation in dairy cattle. Am. J. Physiol. Regul. Integr. Comp. Physiol. 305:R110-R117.

Firkins, J. L., B. S. Oldick, J. Pantoja, C. Reveneau, L. E. Gilligan, and L. Carver. 2008. Efficacy of liquid feeds varying in concentration and composition of fat, nonprotein nitrogen, and nonfiber carbohydrates for lactating dairy cows. J. Dairy Sci. 91:1969-1984.

Gao, J., H. J. Zhang, S. G. Wu, S. H. Yu, I. Yoon, D. Moore, Y. P. Gao, H. J. Yan, and G. H. Qi. 2009. Effect of Saccharomyces cere- visiae fermentation product on immune functions of broilers challenged with Eimeria tenella. Poult. Sci. 88:2141-2151.

Goff, J. P. 2000. Pathophysiology of calcium and phosphorus disorders. Vet. Clin. North Am. Food Anim. Pract. 16:319-337.

Goff, J. P. 2008. The monitoring, prevention, and treatment of milk fever and subclinical hypocalcemia in dairy cows. Vet. J. 176:50-57.

Goff, J. P., and R. L. Horst. 1997. Physiological changes at parturition and their relationship to metabolic disorders. J. Dairy Sci 80:1260-1268.

Guidry, A. J., J. E. Butler, R. E. Pearson, and B. T. Weinland. 1980. $\operatorname{IgA}, \operatorname{IgG}_{1}, \operatorname{IgG}_{2}$, and $\mathrm{BSA}$ in serum and mammary secretion throughout lactation. Vet. Immunol. Immunopathol. 1:329-341.

Harrison, G. A., R. W. Hemken, K. A. Dawson, R. J. Harmon, and K. B. Barker. 1988. Influence of addition of yeast culture supplement to diets of lactating cows on ruminal fermentation and microbial populations. J. Dairy Sci. 71:2967-2975.

Higuchi, H., N. Katoh, T. Miyamoto, E. Uchida, A. Yuasa, and K. Takahashi. 1994. Dexamethasone-induced haptoglobin release by calf liver parenchymal cells. Am. J. Vet. Res. 55:1080-1085.

Humblet, M. F., H. Guyot, B. Boudry, F. Mbayahi, C. Hazen, F. Rollin, and J. M. Godeau. 2006. Relationship between haptoglobin, serum amyloid A, and clinical status in a survey of dairy herds during a 6-month period. Vet. Clin. Pathol. 35:188-193.

Ingvartsen, K. L. 2006. Feeding- and management-related diseases in the transition cows: Physiological adaptations around calving and strategies to reduce feeding-related diseases. Anim. Feed Sci. Technol. 126:175-213.

Ingvartsen, K. L., and J. B. Andersen. 2000. Integration of metabolism and intake regulation: A review focusing on periparturient animals. J. Dairy Sci. 83:1573-1597.

Ingvartsen, K. L., and K. Moyes. 2013. Nutrition, immune function and health of dairy cattle. Animal 7:112-122

Jensen, G. S., A. N. Hart, and A. G. Schauss. 2007. An antiinflammatory immunogen from yeast culture induces activation and alters chemokine receptor expression on human natural killer cells and B lymphocytes in vitro. Nutr. Res. 27:327-335.

Jensen, G. S., K. M. Patterson, J. Barnes, A. G. Schauss, R. Beaman, S. G. Reeves, and L. E. Robinson. 2008a. A double-blind placebo-controlled, randomized pilot study: Consumption of a highmetabolite immunogen from yeast culture has beneficial effects on erythrocyte health and mucosal immune protection in healthy subjects. Open Nutr. J. 2:68-75.

Jensen, G. S., K. M. Patterson, and I. Yoon. 2008b. Nutritional yeast culture has specific anti-microbial properties without affecting healthy flora. Preliminary results. J. Anim. Feed Sci. 17:247-252.

Jensen, G. S., K. M. Patterson, and I. Yoon. 2008c. Yeast culture has anti-inflammatory effects and specifically activates NK cells. Comp. Immunol. Microbiol. Infect. Dis. 31:487-500.

Kelton, D. F., K. D. Lissemore, and R. E. Martin. 1998. Recommendations for recording and calculating the incidence of selected clinical diseases of dairy cattle. J. Dairy Sci. 81:2502-2509.

Kimura, K., T. A. Reinhardt, and J. P. Goff. 2006. Parturition and hypocalcemia blunts calcium signals in immune cells of dairy cattle. J. Dairy Sci. 89:2588-2595.

Lacetera, N., D. Scalia, U. Bernabucci, B. Ronchi, D. Pirazzi, and A. Nardone. 2005. Lymphocyte functions in overconditioned cows around parturition. J. Dairy Sci. 88:2010-2016.

Lecchi, C., F. Dilda, P. Sartorelli, and F. Ceciliani. 2012. Widespread expression of SAA and Hp RNA in bovine tissues after evaluation of suitable reference genes. Vet. Immunol. Immunopathol. 145:556-562.

Maffei, M., M. Funicello, T. Vottari, O. Gamucci, M. Costa, S. Lisi, A. Viegi, O. Ciampi, G. Bardi, P. Vitti, A. Pinchera, and F. Santini. 2009. The obesity and inflammatory marker haptoglobin attracts monocytes via interaction with chemokine (C-C motif) receptor 2 (CCR2). BMC Biol. 7:87.

Magalhães, V. J. A., F. Susca, F. S. Lima, A. F. Branco, I. Yoon, and J. E. P. Santos. 2008. Effect of feeding yeast culture on performance, health, and immunocompetence of dairy calves. J. Dairy Sci. 91:1497-1509. 
Mantis, N. J., N. Rol, and B. Corthésy. 2011. Secretory IgA's complex roles in immunity and mucosal homeostasis. Mucosal Immunol. 4:603-611.

Miller-Webster, T., W. H. Hoover, M. Holt, and J. E. Nocek. 2002. Influence of yeast culture on ruminal microbial metabolism in continuous culture. J. Dairy Sci. 85:2009-2014.

Mulligan, F., L. O'Grady, D. Rice, and M. Doherty. 2006. Production diseases of the transition cows: Milk fever and subclinical hypocalcemia. Ir. Vet. J. 59:697-702.

Nombekela, S. W., M. R. Murphy, H. W. Gonyou, and J. I. Marden. 1994. Dietary preferences in early lactation cows as affected by primary tastes and some common feed flavors. J. Dairy Sci. 77:2393-2399.

Nonnecke, B. J., J. L. Burton, and M. E. Kehrli Jr. 1997. Associations between function and composition of blood mononuclear leukocyte populations from Holstein bulls treated with dexamethasone. J. Dairy Sci. 80:2403-2410.

Nonnecke, B. J., S. T. Franklin, and J. W. Young. 1992. Effects of ketones, acetate, and glucose on in vitro immunoglobulin secretion by bovine lymphocytes. J. Dairy Sci. 75:982-990.

Nonnecke, B. J., K. Kimura, J. P. Goff, and M. E. Kehrli Jr. 2003 Effects of the mammary gland on functional capacities of blood mononuclear leukocyte populations from periparturient cows. J. Dairy Sci. 86:2359-2368.

NRC. 2001. Nutrient Requirements of Dairy Cattle. 7th rev. ed. National Acad. Sci., Washington, DC.

Ohtsuka, H., C. Watanabe, M. Kohiruimaki, T. Ando, D. Watanabe, M. Masui, T. Hayashi, R. Abe, M. Koiwa, S. Sato, and S. Kawamura. 2006. Comparison of two different nutritive conditions against the changes in peripheral blood mononuclear cells of periparturient dairy cows. J. Vet. Med. Sci. 68:1161-1166.

Overton, T. R., and M. R. Waldron. 2004. Nutritional management of transition dairy cows: Strategies to optimize metabolic health. J. Dairy Sci. 87(E. Suppl.):E105-E119.

Quesnell, R. R., S. Klaessig, J. L. Watts, and Y. H. Schukken. 2012. Bovine intramammary Escherichia coli challenge infections in late gestation demonstrate a dominant antiinflammatory immunological response. J. Dairy Sci. 95:117-126.

Ramsing, E. M., J. A. Davidson, P. D. French, I. Yoon, M. Keller, and H. Peters-Fleckenstein. 2009. Effect of yeast culture on peripartum intake and milk production of primiparous and multiparous Holstein cows. Prof. Anim. Sci. 25:487-495.

Reinhardt, T. A., J. D. Lippolis, B. J. McCluskey, J. P. Goff, and R. L. Horst. 2011. Prevalence of subclinical hypocalcemia in dairy herds. Vet. J. 188:122-124.
Robinson, P. H., and J. E. Garrett. 1999. Effect of yeast culture (Saccharomyces cerevisiae) on adaptation of cows to postpartum diets and on lactational performance. J. Anim. Sci. 77:988-999.

Sabedra, D., E. M. Ramsing, C. M. Shriver-Munsch, J. R. Males, W. K. Sanchez, I. Yoon, and G. Bobe. 2012. Haptoglobin is a potential early indicator of postpartal diseases. J. Dairy Sci. 95(Suppl. 2):513. (Abstr.)

Sanchez, W. K., G. D. Poppy, M. A. Guy, and J. E. Garrett. 1997. Influence of yeast on lactational performance and blood mineral concentrations of high producing dairy cows on a commercial dairy. J. Dairy Sci. 80(Suppl. 1):210. (Abstr.)

SAS Institute. 2001. SAS User's Guide: Statistics. Version 9.1. SAS Institute Inc., Cary, NC.

Shainkin-Kestenbaum, R., G. Berlyne, S. Zimlichman, H. R. Sorin, M. Nyska, and A. Danon. 1991. Acute phase protein, serum amyloidA, inhibits IL-1- and TNF-induced fever and hypothalamic $\mathrm{PGE}_{2}$ in mice. Scand. J. Immunol. 34:179-183.

Sharma, N., N. K. Singh, and M. S. Bhadwal. 2011. Relationship of somatic cell count and mastitis: An overview. Asian-australas. J. Anim. Sci. 24:429-438.

Shen, Y. B., X. S. Piao, S. W. Kim, L. Wang, P. Liu, I. Yoon, and Y. G. Zhen. 2009. Effect of yeast culture supplementation on growth performance, intestinal health, and immune response of nursery pigs. J. Anim. Sci. 87:2614-2624.

Shriver-Munsch, C. M., E. M. Ramsing, J. R. Males, W. K. Sanchez, I. Yoon, and G. Bobe. 2011. Effect of various dosages of Saccharomyces cerevisiae fermentation product on reproductive function in multiparous dairy cows. Page 38 in Proc. 13th Annual Northwest Reproductive Sciences Symposium, Corvallis, OR. Oregon State University, Corvallis.

Wallerstedt, E., M. Sandqvist, U. Smith, and C. X. Andersson. 2011 Anti-inflammatory effect of insulin in the human hepatoma cell line HepG2 involves decreased transcription of IL-6 target genes and nuclear exclusion of FOXO1. Mol. Cell. Biochem. 352:47-55.

Xu, L., R. Badolato, W. J. Murphy, D. L. Longo, M. Anver, S. Hale, J. J. Oppenheim, and J. M. Wang. 1995. A novel biologic function of serum amyloid A. Induction of $\mathrm{T}$ lymphocyte migration and adhesion. J. Immunol. 155:1184-1190.

Yoon, I. K., and M. D. Stern. 1996. Effects of Saccharomyces cerevisiae and Aspergillus oryzae cultures on ruminal fermentation in dairy cows. J. Dairy Sci. 79:411-417.

Yoshioka, M., A. Watanabe, N. Shimada, H. Murata, Y. Yokomizo, and Y. Nakajima. 2002. Regulation of haptoglobin secretion by recombinant bovine cytokines in primary cultured bovine hepatocytes. Domest. Anim. Endocrinol. 23:425-433. 